\title{
Pål Kvello
}

Norges teknisk-naturvitenskapelige universitet (NTNU)

Stine Slaatsveen Barstad

Norges teknisk-naturvitenskapelige universitet (NTNU)

Bernt Rønning

Norges teknisk-naturvitenskapelige universitet (NTNU)

\section{Elin Tronsaune Moen}

Norges teknisk-naturvitenskapelige universitet (NTNU)

Ove Østerlie

Norges teknisk-naturvitenskapelige universitet (NTNU)

DOI: http://dx.doi.org/10.5617/adno.7757

\section{Omvendt undervisning versus tradisjonell undervisning i naturfag på ungdomsskolen: en studie av elevers motivasjon, forberedelser og læringsutbytte}

\begin{abstract}
Sammendrag
Som svar på en rekke forespørsler om empiriske data på effekten av omvendt undervisning, har vi utført en mindre studie som sammenligner elevers motivasjon, forberedelser og læringsutbytte mellom omvendt undervisning og tradisjonell undervisning. For å gjøre dette gjennomførte vi en økt med henholdsvis omvendt undervisning og tradisjonell undervisning $\mathrm{i}$ to klasser på ungdomsskolen og målte indikatorer for elevenes læringsutbytte og forberedelse til undervisningen. I tillegg intervjuet vi elever fra begge klassene og tolket våre data med bruk av selvbestemmelsesteorien for motivasjon. Resultatene indikerer at en økt med omvendt undervisning i ungdomsskolen kan fremme autonom motivasjon bedre enn tradisjonell undervisning. Imidlertid bidrar ikke metoden nødvendigvis til at flere elever forbereder seg eller oppnår høyere læringsutbytte, skjønt den kan påvirke elever forskjellig. Videre er det indikasjoner på at forberedelser har vesentlig betydning for læringsutbyttet i både omvendt og tradisjonell undervisning. Denne studien bidrar med empiri til en mangelfull litteratur vedrørende effekten av omvendt undervisning i forhold til tradisjonell undervisning.
\end{abstract}

Nøkkelord: omvendt undervisning, motivasjon, læringsutbytte, ungdomsskolen, selvbestemmelsesteorien 


\title{
Flipped classroom versus traditional teaching of science in lower secondary school: a study of pupils' motivation, preparation and learning outcome
}

\begin{abstract}
In response to numerous requests for empirical data on the effect of flipped classroom, we performed a minor study comparing pupils' motivation, preparation and learning outcome between flipped classroom and traditional teaching. To do this, we conducted a session with flipped classroom and traditional teaching, respectively, in two lower secondary school classes and measured indicators of learning outcome and preparation for class. In addition, we interviewed pupils from both classes and interpreted the data using the self-determination theory of motivation. The results indicate that a session with flipped classroom in upper secondary school can promote development of autonomous motivation better than traditional teaching. However, it does not necessarily result in more pupils preparing for class or a higher learning outcome than traditional teaching, albeit it can affect pupils differently. Furthermore, the study indicates that preparation for class has a strong impact on the learning outcomes in both flipped classroom and traditional teaching. This study compensates for the paucity of empirical data in the literature pertaining to the effect of flipped classroom as compared to traditional teaching.
\end{abstract}

Keywords: flipped classroom, motivation, learning outcome, lower secondary school, self-determination theory

\section{Innledning}

Til tross for teoretisk støtte og stor entusiasme for omvendt undervisning (flipped classroom) i senere tid, anses effekten av metoden fortsatt ikke som evidensbasert (Abeysekera \& Dawson, 2015; Chen, Lui \& Martinelli, 2017; Chen, Monrouxe, Lu, Jenq, Chang, Chang \& Chai, 2018; Gillette, Rudolph, Kimble, RockichWinston, Smith \& Broedel-Zaugg, 2018). En viktig årsak til dette er manglende konsensus om definisjonen av metoden. Lage, Platt og Treglia (2000) hevder for eksempel at omvendt undervisning betyr at aktivitetene som tradisjonelt har funnet sted i klasserommet, nå finner sted utenfor klasserommet og vice versa. Denne definisjonen følger logikken i å bruke begrepet «omvendt», men er problematisk i forskningssammenheng fordi den avhenger av hva som har blitt gjort tradisjonelt, noe som synes å variere mellom ulike studier. Abeysekera og Dawson (2015) definerer metoden som et sett av pedagogiske tilnærminger som flytter mesteparten av informasjonsoverføringen ut av klasserommet, og som bruker tiden i klasserommet til læringsaktiviteter som er aktive og sosiale, og som krever at studentene fullfører aktiviteter før eller etter undervisning. Denne definisjonen er mer spesifikk og entydig, men gir fortsatt mye rom for variasjon blant aktivitetene både i og utenfor klasserommet. Bishop og Verleger (2013) hevder at 
omvendt undervisning består av to deler: en del med interaktive gruppelæringsaktiviteter i klasserommet, og en del med direkte datamaskinbasert, individuell instruksjon utenfor klasserommet. Denne definisjonen setter videre begrensninger på teknologien og organiseringen av elever i forbindelse med hjemmearbeidet, noe som gjør den bedre egnet for vitenskapelig, eksperimentell testing.

Forskjellige definisjoner av omvendt undervisning har ført til ulik design av metoden i studier som har undersøkt den. Basert på definisjonen til Bishop og Verleger (2013), ble det for eksempel funnet at kun 10 av 24 studier hadde brukt en rendyrket omvendt undervisningsdesign (Bishop \& Verleger, 2013). De fleste ble definert som delvis omvendte enten fordi forberedelsen til undervisning var tekstbasert istedenfor video, eller at noen av aktivitetene var valgfrie. Dette gjør det utfordrende å sammenligne resultater på tvers av studier, og vanskeliggjør derfor en evidensbasert konklusjon om effekten av metoden. For å sammenligne omvendt undervisning med andre undervisningsmetoder har noen studier inkludert kontrollgrupper. Problemet er igjen at svært få studier har brukt samme definisjon av omvendt undervisning. I tillegg er ofte kontrollgruppene så marginalt beskrevet at det er vanskelig å vurdere hva som er blitt gjort. For eksempel, blant de 24 studiene undersøkt i Bishop og Verleger (2013) var det kun én av de ti studiene med rendyrket omvendt undervisningsdesign som inkluderte en kontrollgruppe. Denne studiens kontroll var tradisjonell undervisning som ble beskrevet som en passiv læringsform hvor informasjonen ble gitt i form av lesestoff og forelesning, og hjemmearbeid ble gitt i form av oppgaver som måtte gjennomføres før neste forelesning (Day \& Foley, 2006). Selv om nyere studier har en forbedret forskningsdesign (Chen et al., 2017), bærer de fortsatt preg av varierende undervisningsdesign eller mangelfulle opplysninger om nettopp dette, noe som sannsynligvis er årsaken til ulike konklusjoner om effekten av den omvendte undervisningsmetoden (Chen et al., 2017; Chen et al., 2018; Cheng, Ritzhaupt \& Antonenko, 2019; Gillette et al., 2018). På grunn av disse utfordringene har mange påpekt behovet for en klar definisjon, grundigere beskrivelser av designen og mer velkontrollerte, vitenskapelige undersøkelser av den omvendte undervisningsmetoden (Abeysekera \& Dawson, 2015; Bishop \& Verleger, 2013; Chen et al., 2018; Cheng et al., 2019; Hall \& DuFrene, 2016; Hu, Gao, Ye, Ni, Jiang \& Jiang, 2018; Kim, Kim, Khera \& Getman, 2014; Krumsvik \& Jones, 2016).

\section{Tidligere forskning}

Studiene av omvendt undervisning er mange og mangfoldige (Lo \& Hew, 2017). Vi har imidlertid begrenset denne litteraturgjennomgangen til eksperimentelle studier med kontrollgruppe, som undersøker læringsutbytte og motivasjon, og som har benyttet lignende definisjon av omvendt undervisning som Bishop og Verleger (2013). Basert på dette utvalget tyder forskning på at omvendt undervisning på universitetsnivå kan forbedre læringsutbytte sammenlignet med tradisjonell undervisning. Denne konklusjonen er hovedsakelig basert på sammenligning 
av sluttkarakterer for kurs ved forskjellige utdanninger, inkludert mekanikkingeniør (Mason, Shuman \& Cook, 2013), audiologi (Berg, Ibrahim, Magaster \& Salbod, 2015), datavitenskap (Day \& Foley, 2006), farmasi (McLaughlin, Roth, Glatt, Gharkholonarehe, Davidson, Griffin, Esserman \& Mumper, 2014; Pierce \& Fox, 2012) og sykepleie (Missildine, Fountain, Summers \& Gosselin, 2013). Med unntak av (Missildine et al., 2013) synes også de fleste studentene å foretrekke omvendt undervisning fremfor tradisjonell (Berg et al., 2015; Day \& Foley, 2006; Mason et al., 2013; McLaughlin et al., 2014; Pierce \& Fox, 2012), og to av studiene indikerer at denne holdningen forsterkes over tid (Day \& Foley, 2006; Mason et al., 2013). Dette blir uttrykt gjennom selvrapportering i etterkant av kurs med omvendt undervisning og begrunnes ofte med bruk av film i forkant, spesielt det at de selv kan styre når, hvor og hvordan de vil se den. Imidlertid synes det alltid å være noen studenter som foretrekker tradisjonell undervisningsmetode, og begrunnelsene inkluderer blant annet at omvendt undervisning krever mer arbeid, og at noen ikke ser verdien av de interaktive læringsaktivitetene (Missildine et al., 2013). En utfordring med studiene nevnt ovenfor er imidlertid at sluttkarakterer for et kurs ikke nødvendigvis sier noe om læringsutbytte når man ikke kjenner elevenes utgangspunkt. Kun Pierce og Fox (2012) benyttet en relevant pretest for å kontrollere for dette, men denne ble imidlertid kun gitt til studentene som fikk omvendt undervisning. Relevant i dette tilfellet vil si at testspørsmålene var knyttet til læringsmålene for kurset, i motsetning til å bruke informasjon fra andre kurs med forskjellig innhold og fra tidligere år. I tillegg er det relativt store variasjoner mellom studiene i hva som inngår i kontrollgruppen som de kaller tradisjonell undervisning. Dette inkluderer alt fra ren forelesning til forelesning kombinert med gruppeoppgaver, individuelle oppgaver, laboratoriearbeid, casestudier eller prosjektarbeid.

Også på videregående nivå ser det ut til at omvendt undervisning kan forbedre læringsutbytte sammenlignet med tradisjonell undervisning. Dette er basert på prestasjoner i fag som kjemi (Schultz, Duffield, Rasmussen \& Wageman, 2014), engelsk leseforståelse og informasjons- og kommunikasjonsteknologi (Huang \& Hong, 2016) og brodesign innen ingeniørfag (Chao, Chen \& Chuang, 2015). I tillegg synes de fleste elevene å foretrekke den omvendte undervisningsmetoden fremfor den tradisjonelle, noe som i likhet med studentene på universitetet begrunnes med filmen. Imidlertid er utfordringen her at kun én av studiene inkluderte relevant pretest (Huang \& Hong, 2016).

På ungdomsskolen er det derimot gjort funn som tyder på at omvendt undervisning ikke fører til bedre læringsutbytte enn tradisjonell undervisning (Chen, 2016; Clark, 2015; Kirvan, Rakes \& Zamora, 2015). Imidlertid viste elevene i Kirvan et al. (2015) bedre læringsutbytte med omvendt undervisning på én av tre oppgaver i algebra. Dette er også den eneste av de tre studiene som benyttet pretest for å måle læringsutbytte. I tillegg er det den eneste som beskriver den tradisjonelle undervisningsmetoden, noe som avslører at den kanskje er på grensen til det man kan kalle tradisjonell, siden den kun inkluderer 10-15 min forelesning og 15-20 
min samarbeidslæring og utforskende problemer. Videre ser det heller ikke ut til at elevene på ungdomsskolen er mer fornøyd med den omvendte undervisningsmetoden. Basert på spørreundersøkelsen i Clark (2015) synes elevene å være like fornøyd med omvendt som tradisjonell, og i Chen (2016) synes elevene derimot å være mindre fornøyd med den omvendte undervisningen. De begrunner dette med at elevene hadde vanskelig for å akseptere den nye undervisningsmetoden, spesielt det å se videoer og sette seg inn i nytt fagstoff hjemme, noe de ikke var vant til. Mange elever hadde derfor vanskelig for å delta aktivt i klasseaktivitetene.

En oppsummering av dette indikerer at omvendt undervisning både på universitetsnivå og i videregående skole synes å gi elevene høyere læringsutbytte og større motivasjon enn tradisjonell undervisning. I ungdomsskolen ser det derimot ut til at elevenes læringsutbytte og motivasjon er lik for de to undervisningsmetodene. En evidensbasert konklusjon basert på disse studiene er likevel problematisk på grunn av variasjoner i, eller mangelfulle beskrivelser av kontrollgruppen, samt en lite kontrollert studiedesign. Som et steg i retning av å fylle disse hullene har vi gjennomført en mindre studie av den omvendte undervisningsmetoden hvor vi har etterstrebet en rendyrket omvendt undervisningsdesign som definert av Bishop og Verleger (2013), grundige beskrivelser av både omvendt og tradisjonell undervisning, samt en vitenskapelig fremgangsmåte med kontrollgruppe. Vi har sammenlignet elevenes motivasjon, forberedelser og læringsutbytte av omvendt undervisning med tradisjonell undervisning over totalt fire økter hos to klasser på 9. trinn. Informasjonen er blitt innhentet ved hjelp av intervju, selvrapportering i form av håndsopprekning i klassen, samt pre- og posttester. Vår problemstilling er: Hvordan påvirker en økt med omvendt undervisning elevenes motivasjon, forberedelser og leringsutbytte i forhold til tradisjonell undervisning?

\section{Teoretisk rammeverk}

For å tolke resultatene fra intervjuet har vi brukt selvbestemmelsesteorien (SDT: Deci \& Ryan, 2008a) og sosiokulturell læringsteori (Vygotsky, 1978). Ifølge SDT deles motivasjon inn i to hovedtyper, autonom motivasjon og kontrollert motivasjon. Autonom motivasjon innebærer atferd styrt av egen fri vilje, mens kontrollert motivasjon innebærer atferd styrt av ytre press og krav. Ifølge teorien er typen motivasjon viktigere enn mengden motivasjon for å kunne forutsi folks selvregulerte atferd, der autonomt motiverte personer antas å ha bedre selvregulering enn personer som drives av kontrollert motivasjon (Hagger, Hardcastle, Chater, Mallett, Pal \& Chatzisarantis, 2014). Autonom motivasjon er vist å resultere i bedre karakterer, mer kreativitet, bedre utholdenhet på skolen og i idrett, høyere produktivitet og mindre utbrenthet i jobb, sunnere livsstil og bedre psykologisk helse (Deci \& Ryan, 2008a).

For å oppnå autonom motivasjon, vektlegger SDT at læringsomgivelsene må tilrettelegges slik at de tilfredsstiller elevenes følelse av kompetanse, autonomi og 
tilhørighet (Abeysekera \& Dawson, 2015; Deci \& Ryan, 2008a). Kompetanse er viktig for at elevene skal føle at de behersker kunnskap, ferdigheter og atferder som kreves i gitte sosiale sammenhenger. Tilhørighet trenger elevene for å føle at de er en del av en gruppe, mens autonomi får elevene til å føle at de selv har kontroll og er uavhengige. Dersom elevene ikke opplever autonomi, men kun en viss grad av kompetanse og tilhørighet, vil de utvikle kontrollert motivasjon (Deci \& Ryan, 2008b). Mangel på tilfredsstillelse av alle tre behovene fører til at motivasjon uteblir. I lys av SDT kan man derfor argumentere for at enhver form for undervisning som skaper læringsomgivelser som tilfredsstiller elevenes behov for kompetanse, tilhørighet og autonomi vil fremme elevers autonome motivasjon.

Ifølge Abeysekera og Dawson (2015) har den omvendte undervisningsmetoden en design som synes å fremme kompetanse, tilhørighet og autonomi bedre enn tradisjonell undervisning. Omvendt undervisning tilbyr elevene kompetanse gjennom å inkludere forberedelse til undervisning med påfølgende læringsaktiviteter i klasserommet hvor elevene kan få bekreftet sin kompetanse. Til forskjell fra tradisjonell undervisning er klasseromaktivitetene i omvendt undervisning organisert som interaktive gruppearbeid hvor læreren er tilstede for å veilede og stimulere elevene til aktiv deltakelse, noe som ifølge sosiokulturell læringsteori (Vygotsky, 1978) fremmer kompetanseutviklingen. Dette støttes også av empiriske studier som viser at elever både opplever og oppnår mer kompetanse når de er aktive deltakere enn når de er passive mottakere (Gauci, Dantas, Williams \& Kemm, 2009; Prince, 2004; Thaman, Dhillon, Saggar, Gupta \& Kaur, 2013). Omvendt undervisning tilbyr elevene tilhørighet gjennom interaktive gruppeaktiviteter i klasserommet med læreren som veileder. Dette blir i mindre grad benyttet i tradisjonell undervisning hvor elevene hovedsakelig arbeider individuelt. Omvendt undervisning tilbyr elevene autonomi blant annet gjennom forberedelser i form av video, noe som gir frihet med tanke på hvor, når og hvordan forberedelsen skal gjennomføres. Men det som kanskje spesielt skiller metoden fra tradisjonell undervisning når det gjelder tilrettelegging for autonomi, er klasseromsaktivitetene. Disse gir elevene mulighet til å bidra med egne ideer, i motsetning til tradisjonell undervisning hvor elevene stort sett er passive tilhørere (Abeysekera \& Dawson, 2015).

\section{Materiale og metode}

Vi samlet inn og analyserte data ved bruk av både kvalitative og kvantitative metoder. Kvalitative data ble analysert ved hjelp av programvaren NVivo (NVivo for Windows, versjon 11), mens kvantitative data ble analysert ved hjelp av programvaren SPSS (IBM SPSS statistikk for Windows, versjon 24.0). 


\section{Studiens design}

I denne studien brukte vi en kvasieksperimentell design (Shadish, Cook \& Campbell, 2002), som er vanlig i skolesammenheng siden enhetene som skal undersøkes (elevene) ikke er tilfeldig fordelt i gruppene (klasser) som skal sammenlignes (Berg et al., 2015; Day \& Foley, 2006; Freeman, Eddy, McDonough, Smith, Okoroafor, Jordt \& Wenderoth, 2014). Utfordringen med denne type design er at gruppene i utgangspunktet kan være forskjellige. For å styrke studiens validitet var det derfor viktig å gjøre tiltak for å minimalisere potensielle forskjeller mellom gruppene. I denne studien ble det gjort flere slike tiltak. Først og fremst ble undersøkelsen gjort på to klasser på samme trinn (9. trinn) med tilnærmet lik kjønnsfordeling. Den ene klassen (A) besto av 24 elever hvorav 10 var jenter og 14 var gutter, og den andre klassen (B) besto av 22 elever hvorav 10 var jenter og 12 var gutter. Videre hadde klassene samme lærer i naturfag, som også var deres kontaktlærer, noe som var viktig for å minimalisere potensielle effekter av å ha bakgrunn fra ulike lærere. Undervisningen i studien ble imidlertid gjennomført av en av forskningsgruppens medlemmer (heretter kalt underviseren) for å sikre at forskningsdesignen ble fulgt og for å unngå ekstra arbeidsbelastning på kontaktlæreren. Kontaktlærer var til stede i undervisningen. Vi ble opplyst om at det var noe mer uro i klasse B enn i klasse A, men at klassenes gjennomsnittlige standpunktkarakterer fra 8. trinn var tilnærmet like (klasse A: 3,9, klasse B: 3,7). Videre ble begge klassene utsatt for både omvendt undervisning og tradisjonell undervisning, noe som tillot sammenligning innad i hver gruppe og mellom gruppene, samt at vi kunne betrakte begge klassene som én gruppe og dermed sammenligne betydningen av de to undervisningsmetodene for alle 46 elevene (figur 1 ).

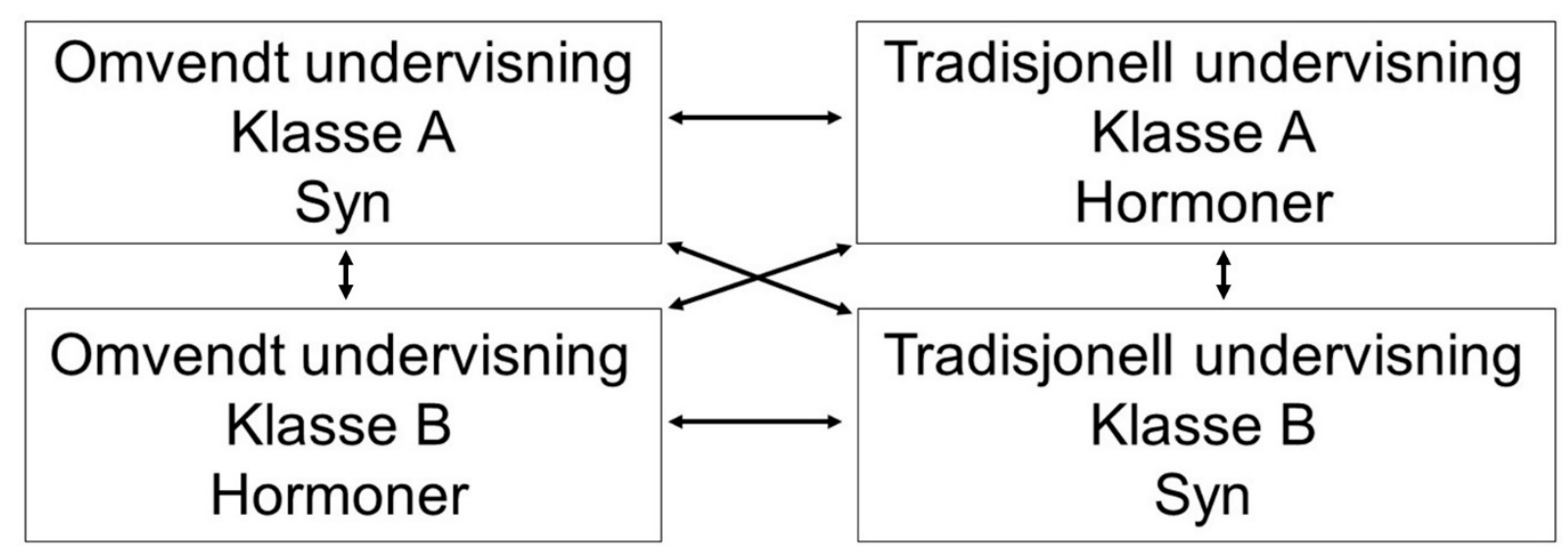

Figur 1. Studiens kvasieksperimentelle design. Begge klassene ble eksponert for begge undervisningsmetodene. Pilene viser hvilke grupper som ble sammenlignet.

Utfordringen her var at elevene måtte ha forskjellige tema i omvendt og tradisjonell undervisning. For å minimalisere potensielle effekter av ulike tema valgte vi temaene syn og hormoner. Kapitlene om disse temaene har omtrent like mange fagbegrep (syn: 27 og hormoner: 29). I tillegg er det lite overlapp av begrepene kun fagbegrepet pupille blir brukt i begge kapitlene - noe som var viktig for å 
redusere muligheten for at elevene kunne benytte kunnskapen som de ervervet fra første undervisningstema til å besvare spørsmålene knyttet til andre undervisningstema. Videre utgjør disse temaene hvert sitt kompetansemål i naturfag etter 10. trinn i læreplanen og ble hentet fra samme læreverk for 9. trinn, noe som skulle sikre at det faglige nivået var tilnærmet likt.

\section{Eksperimentell gruppe og kontrollgruppe}

Vår eksperimentelle gruppe var omvendt undervisning som definert av Bishop og Verleger (2013). Vår kontrollgruppe var tradisjonell undervisning, inspirert av Telhaug og Mediås (2003), hvor lærerrollen er autoritær og elevrollen passiv. Det er læreren som velger innhold og undervisningsmetoder; elevene har ingen medvirkning, de tilpasser seg. Begge gruppene er nærmere beskrevet under gjennomføring av studien lengre ned.

\section{Innsamling og analyse av kvalitativt datamateriale Elevenes motivasjon}

For å belyse hvordan omvendt undervisning påvirker elevenes motivasjon, gjennomførte vi et semistrukturert intervju (vedlegg 1) som beskrevet av (Kvernmo, 2010), og diskuterte de analyserte utsagnene i lys av SDT. Intervjuet besto av fem spørsmål og ble gjennomført som et gruppeintervju bestående av fire elever og en intervjuer (underviseren). På grunn av det lille utvalget ble validiteten etterstrebet gjennom følgende kriterier for utvelgelse: Det måtte være en gutt og ei jente fra hver klasse, de måtte ha vært til stede i undervisningen, de måtte ha gjort hjemmearbeidet, og de måtte ha et variert karaktergrunnlag i naturfag. Grunnen til at vi valgte gruppeintervju var hovedsakelig for å gjøre intervjusituasjonen mindre skremmende, skjønt vi var oppmerksomme på at en slik intervjusituasjon kunne føre til at elevene påvirket hverandre. Videre valgte vi å ikke ha kontaktlærer til stede for å unngå at forholdet mellom elev og kontaktlærer skulle påvirke svarene. Intervjuet ble gjennomført i et egnet rom på skolen for å sikre at elevene følte de kunne snakke fritt uten å bli observert eller hørt av utenforstående, samtidig som de var på et kjent sted. Intervjuer opplyste også om anonymiteten og mulighetene for å trekke seg ved et senere tidspunkt dersom elevene ikke ville at uttalelsene deres skulle bli del av studien. Intervjuene ble gjennomført i skoletiden slik at elevene ikke skulle føle tidspress.

Datamaterialet fra intervjuet ble først analysert med åpen koding som beskrevet i Nilssen (2012, s. 78-79). Alle utsagn fra informantene som uttrykte en opplevelse av undervisningsmetodene ble markert. Disse utsagnene ble kategorisert basert på en kombinasjon av vår teoretiske forforståelse (SDT) og innholdet i intervjuet, som anbefalt i Holter (1996). 


\section{Innsamling og analyse av kvantitativt datamateriale Måling av elevenes laeringsutbytte}

For å belyse hvordan omvendt undervisning påvirker elevenes læringsutbytte, ble det utarbeidet kunnskapstester i form av identiske pre- og posttester (vedlegg 2), noe som er vanlig i kvasieksperimentell design blant annet for å kontrollere for potensielle forskjeller i gruppenes utgangspunkt (Shadish et al., 2002). Testene besto av ti spørsmål, hvert med fire alternative svar hvor kun ett var riktig. Spørsmålene var sterkt koblet til lærebokens innhold (Eureka 9: Hannisdal, Haugan \& Munkvik, 2007, s. 105, 114-117, 75-79), filmen, oppgavene elevene jobbet med i klasserommet både under den omvendte og den tradisjonelle undervisningen (vedlegg 3), samt til læreplanens kompetansemål. Noen avveininger måtte imidlertid tas for å etterstrebe elevaktive oppgaver i den omvendte undervisningen samtidig som vi måtte ta hensyn til at oppgavene i den tradisjonelle undervisningen allerede var bestemt $\mathrm{i}$ henhold til læreboken.

For å analysere dataene ble besvarelsene på kunnskapstestene gitt poeng. Riktig svaralternativ ble gitt ett poeng, mens feil alternativ ble gitt null poeng. For hver elev ble poengene på de ti spørsmålene på henholdsvis pretest og posttest summert. For å undersøke potensielle forskjeller mellom klassenes utgangspunkt sammenlignet vi resultatene fra pretesten i klasse A med klasse B ved hjelp av en uparet $t$-test. Vi kjørte også en uparet Mann-Whitney $\mathrm{U}$ Test siden en av gruppene ikke var normalfordelt (vedlegg 8, tabell B). Fordelingen av datamaterialet ble undersøkt med en Shapiro-Wilk test, hvor verdier høyere enn 0,05 ble ansett som normalfordelt. Alt under ble ansett som signifikant forskjellige fra normal. For å finne ut om elevene oppnådde et signifikant læringsutbytte med de to undervisningsmetodene, sammenlignet vi gjennomsnittet for posttesten med pretesten ved hjelp av en Wilcoxon signed-ranks test. I tillegg beregnet vi effektstørrelse basert på Cohens $d$ (Cohen, 1992), som ifølge Hattie (2012, s. 271-273) kan brukes som et objektivt mål på elevers progresjon i undervisningssammenheng. Hvilken undervisningsmetode som resulterte i størst læringsutbytte ble deretter funnet ved å sammenligne læringsutbyttet (differansen mellom posttest og pretest) for tradisjonell undervisning med omvendt undervisning ved hjelp av en $t$-test. Fordelingen av disse dataene var tilstrekkelig normalfordelt for å gjøre en slik test (vedlegg 6, tabell C; vedlegg 7, tabell C og F). Potensielle interaksjoner mellom variablene ble testet med en generell lineær modell.

\section{Måling av elevenes forberedelser}

For å belyse hvordan omvendt undervisning påvirker elevenes forberedelser målte vi hvor mange elever som hadde gjennomført hjemmearbeidet. Dette ble gjort i begynnelsen av hver undervisningsøkt ved at underviseren spurte elevene hvor mange som hadde gjort hjemmearbeidet. Elevene svarte ved å rekke opp hånden og underviseren registrerte antallet. Det ble imidlertid ikke registrert hvilke elever dette var. For å styrke validiteten i denne delen av studien ble kontaktlæreren bedt 
om å gå ut av klasserommet før elevene svarte. Hensikten med dette var å redusere sjansen for at forholdet mellom kontaktlærer og elev skulle påvirke svarene.

For å analysere disse dataene sammenlignet vi andelen elever som hadde gjort hjemmearbeidet i omvendt undervisning med tradisjonell undervisning ved hjelp av en binomial test der «gjort hjemmearbeid» ble definert som 1 og «ikke gjort hjemmearbeid» som 0 . Samme test ble brukt for å undersøke om de to undervisningsmetodene påvirket elevene i klasse A og B forskjellig, og for å undersøke om det var noen forskjell mellom klassene, uavhengig av metode.

\section{Gjennomføring av studien}

Første intervensjonsperiode startet med at begge klassene ble gitt en kunnskapstest (pretest) innenfor temaet syn. Elevene ble ikke opplyst om at de senere ville få en posttest. Deretter, samme dag, ble begge klassene gitt hjemmearbeid i temaet syn som en del av ukeplanen. Elevene ble også muntlig informert om dette hjemmearbeidet i timen. For klasse A som skulle ha omvendt undervisning, var dette hjemmearbeidet å se en videoforelesning om temaet syn som hadde tilnærmet samme innhold som de fem sidene om syn (s. 105 og 114-117) i læreboken Eureka 9 (Hannisdal, Haugan \& Munkvik, 2007). Videoforelesningen ble laget av underviseren som hadde erfaring med å lage undervisningsvideoer fra en tidligere bacheloroppgave i lærerutdanningen, samt noe erfaring fra undervisning i grunnskolen. Videoen inkluderte litt om lys, lysets gang i øyet, øyets anatomi, og funksjonen til de ulike delene. Presentasjonen var muntlig og inkluderte figurer. For klasse B som skulle ha tradisjonell undervisning, var hjemmearbeidet å lese de fem sidene om syn i læreboken Eureka 9. Dette ble gjort for at begge klassene skulle få tilsvarende informasjon før undervisningen og dermed gi begge klassene lik mulighet til å forberede seg.

Fire dager etter pretesten ble første undervisning gjennomført i klasse A med undervisningsformen omvendt undervisning om temaet syn. Undervisningen var en økt på 60 minutter som ble gjennomført av underviseren (tabell 1).

Tabell 1. Oversikt over omvendt undervisningsøkt

\begin{tabular}{|l|l|}
\hline Tid & Omvendt undervisning \\
\hline $5 \mathrm{~min}$ & Underviseren registrerer antall elever som har gjort hjemmearbeid (video) \\
\hline $5 \mathrm{~min}$ & Underviseren introduserer gruppeoppgavene for elevene \\
\hline $35 \mathrm{~min}$ & Elevene arbeider med gruppeoppgaver \\
\hline $15 \mathrm{~min}$ & Underviseren oppsummerer timen med å stille spørsmål. Elevene rekker opp hånden for å svare \\
\hline
\end{tabular}

Etter at underviseren hadde introdusert gruppeaktivitetene ble elevene delt inn i fem grupper, hver på fire eller fem elever, før de ble satt i arbeid. Gruppeaktivitetene besto av fem forskjellige oppgaver som var designet med mål om å stimulere til praktisk arbeid og diskusjon i gruppen, men likevel ha fasitsvar slik at læringsutbyttet lett kunne måles med pre- og posttester (vedlegg 4). Sju minutter ble avsatt til hver oppgave. Under aktivitetene førte underviseren faglig dialog med elevene, og sjekket at oppgavene ble forstått. Elevene fikk bruke lærebøkene 
i disse aktivitetene. Timen ble oppsummert ved at underviseren stilte åtte spørsmål (vedlegg 5).

To dager etter omvendt undervisning i klasse A gjennomførte vi tradisjonell undervisning i klasse $\mathrm{B}$ om temaet syn. Dette var også en økt på 60 minutter som begynte og sluttet på samme måte som omvendt undervisning (tabell 2). Frontalundervisningen ble gitt ved hjelp av PowerPoint og besto av samme innhold, gitt i samme rekkefølge som filmen i den omvendte undervisningen. Innholdet ble imidlertid ikke presentert helt likt på setningsnivå fordi underviseren ikke brukte filmmanuset i klasserommet. Mens elevene arbeidet gikk underviseren rundt og svarte på spørsmål, og sjekket at oppgavene ble forstått. Elevene fikk også her bruke lærebøkene.

Tabell 2. Oversikt over tradisjonell undervisningsøkt

\begin{tabular}{|l|l|}
\hline Tid & Tradisjonell undervisning \\
\hline 5 min & Underviseren registrerer antall elever som har gjort hjemmearbeid (tekst) \\
\hline 20 min & Underviseren gir frontalundervisning \\
\hline 20 min & Elevene arbeider individuelt med oppgaver i læreboken (nøkkelspørsmålene) \\
\hline 15 min & Underviseren oppsummerer timen med å stille spørsmål. Elevene rekker opp hånden for å svare \\
\hline
\end{tabular}

Andre intervensjonsperiode startet uken etter første intervensjonsperiode. Her ble samme fremgangsmåte fulgt, men denne gangen var temaet hormoner (Eureka 9, s. 75-79), og nå var det klasse A som fikk tradisjonell undervisning og klasse $\mathrm{B}$ som fikk omvendt undervisning.

Tolv dager etter siste undervisning i andre intervensjonsperiode ble begge klassene gitt en kunnskapstest (posttest) som var identisk med pretestene på syn og hormoner. Deretter ble det gjennomført intervju samme dag.

\section{Resultater}

\section{Effekten av omvendt undervisning på elevenes læringsutbytte}

Det første vi ønsket å finne ut, var hvilken effekt omvendt undervisning hadde på elevenes læringsutbytte sammenlignet med tradisjonell undervisning. For å finne svar på dette måtte vi først verifisere at undervisningsmetodene i det hele tatt resulterte i et læringsutbytte hos elevene. Dette ble bekreftet for omvendt undervisning ved at elevene, uavhengig av klasse, oppnådde en statistisk signifikant høyere poengsum på posttesten enn på pretesten $(Z=-2.158, p=0.031)$, men ikke for tradisjonell undervisning ( $Z=-1.893, p=0.058$ ) (vedlegg 6 , tabell A og B). Når vi etterpå sammenlignet elevenes læringsutbytte av omvendt undervisning med tradisjonell undervisning, fant vi ingen statistisk signifikant forskjell ( $t(87)$ $=-0.119, p=0.906$ ) (vedlegg 6, tabell C). Det var heller ingen signifikante interaksjoner mellom de testede variablene: klasse og metode, og klasse og tema. Interaksjon mellom metode og tema kunne ikke testes på grunn av studiens kvasieksperimentelle design. De numeriske verdiene for læringsutbytte var imidlertid litt høyere for omvendt undervisning $(\mu=0.86)$ enn for tradisjonell $(\mu=0.80)$. 
Når vi undersøkte klassene hver for seg, oppdaget vi at dette hovedsakelig skyldtes elever fra klasse A, som i gjennomsnitt hadde et numerisk høyere læringsutbytte med omvendt undervisning $(\mu=1,77)$ enn med tradisjonell $(\mu=$ 1,27) (figur 2, og vedlegg 7 , tabell $A, B$ og $C$ ).
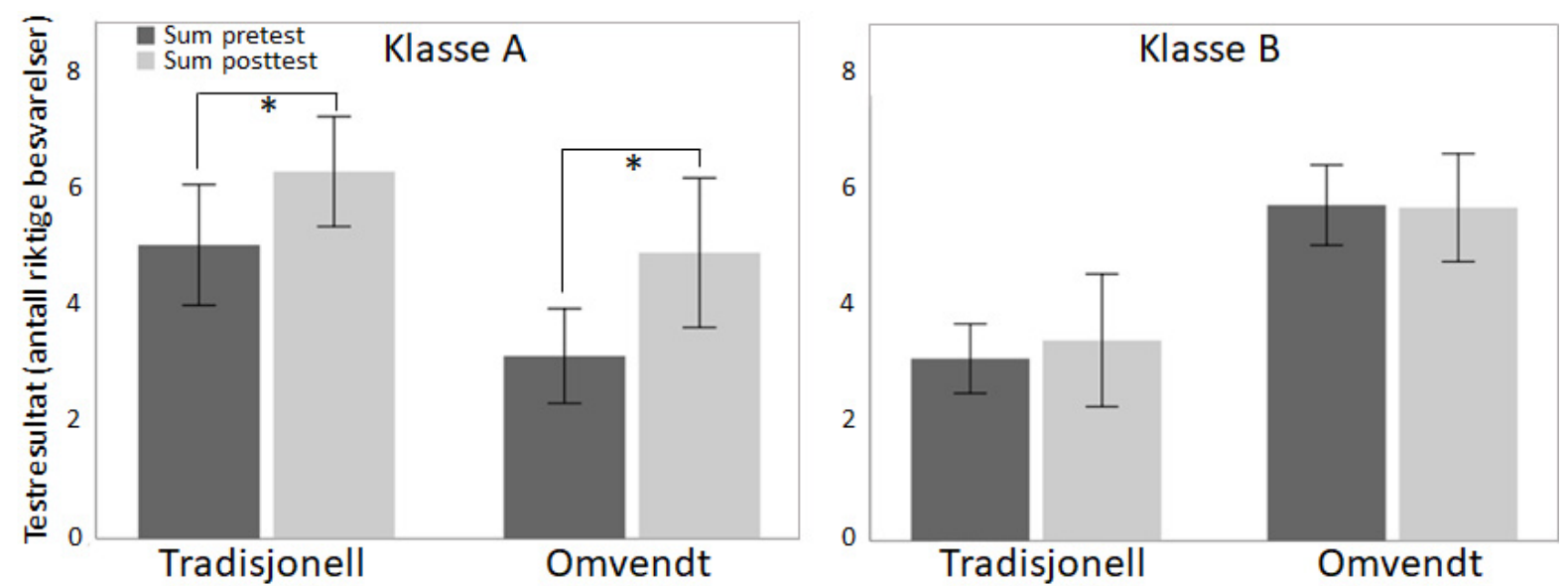

Figur 2. Elevenes gjennomsnittlige poengsum på pretest og posttest i forbindelse med tradisjonell undervisning og omvendt undervisning. Høyeste mulige poengsum var 10.

${ }^{*} p<0.05$; Related-samples Wilcoxon Signed Rank Test. Feilfelt representerer 95\% konfidensintervall.

Klasse B hadde derimot et numerisk høyere læringsutbytte med tradisjonell undervisning (tradisjonell: $\mu=0.32$, omvendt: $\mu=-0.05$ ), men læringsutbyttet hos denne klassen var imidlertid ikke signifikant med noen av undervisningsmetodene (figur 2, og vedlegg 7, tabell D, E og F). Hos klasse A var læringsutbyttet signifikant med begge undervisningsmetodene, men kun for omvendt undervisning var det signifikant høyere enn hos klasse B $(t(42)=2.478, p=$ 0.017). For å undersøke om denne forskjellen kunne ha noe å gjøre med eventuelle forskjeller i bakgrunnskunnskap, sammenlignet vi pretestene i klasse A med klasse $\mathrm{B}$. Her fant vi ingen signifikante forskjeller, hverken når vi testet for begge temaene samlet $(t(90)=-7.49, p=0.456$, og vedlegg 8 , tabell A), eller temaene hver for seg (syn: $Z=-0.26, p=0.795$; hormoner: $(t(44)=-1.306, p=0.199$, og vedlegg 8 , tabell $\mathrm{B}$ og C). Vi fant imidlertid forskjeller mellom temaene. Det vil si at begge klassene i gjennomsnitt hadde bedre bakgrunnskunnskap om hormoner enn om syn.

For å få en mer generaliserbar måleenhet for læringsutbytte, beregnet vi også effektstørrelsen (Cohens $d$ ) (Cohen, 1992). For klasse A var denne verdien både på tradisjonell $(d=0.55)$ og omvendt undervisning $(d=0.75)$ mellom det Cohen regner som medium og stor effekt (henholdsvis $d=0.5$ og $d=0.8$ ). Det er også høyere enn det Hattie (2012, s. 271-273) mener man bør forvente av progresjon i læringen $(d=0.4)$. For klasse $\mathrm{B}$ derimot, var denne størrelsen både på tradisjonell ( $d=0.16)$ og omvendt undervisning $(d=-0.02)$ mindre enn det Cohen regner som liten effekt $(d=0.2)$, og under Hatties forventede progresjon i læringen.

En oppsummering av dette viser at elevenes læringsutbytte ikke var signifikant forskjellig mellom omvendt og tradisjonell undervisning. Imidlertid var det numeriske forskjeller i favør av den omvendte undervisningen. Dette skyldes 
hovedsakelig klasse A som hadde et signifikant læringsutbytte med begge undervisningsmetodene, og som var numerisk høyere med omvendt undervisning. Klasse B derimot, hadde numerisk høyere læringsutbytte med tradisjonell undervisning, men læringsutbyttet var ikke signifikant med noen av metodene.

\section{Betydningen av omvendt undervisning for elevenes forberedelse}

Det neste vi ønsket å finne ut av, var om den omvendte undervisningsmetodens bruk av video istedenfor tekstbasert materiale som hjemmearbeid påvirket elevenes forberedelser. For å belyse dette analyserte vi vårt kvantitative datamateriale som målte hvor mange elever som sa de hadde gjennomført hjemmearbeidet. Her fant vi ingen statistisk signifikant forskjell mellom undervisningsmetodene når vi så på klassene samlet ( $p=0.425$, og vedlegg 9 , tabell $\mathrm{A})$.

Når vi så på klassene hver for seg derimot, fant vi forskjeller både mellom metodene og klassene. I klasse A var andelen elever som hadde gjort hjemmearbeidet $\mathrm{i}$ omvendt undervisning (video) høyere enn tradisjonell undervisning (tekst) (figur 3, og vedlegg 9 tabell B), mens i klasse B var det en tendens til det motsatte (figur 3 , og vedlegg 9 tabell C).

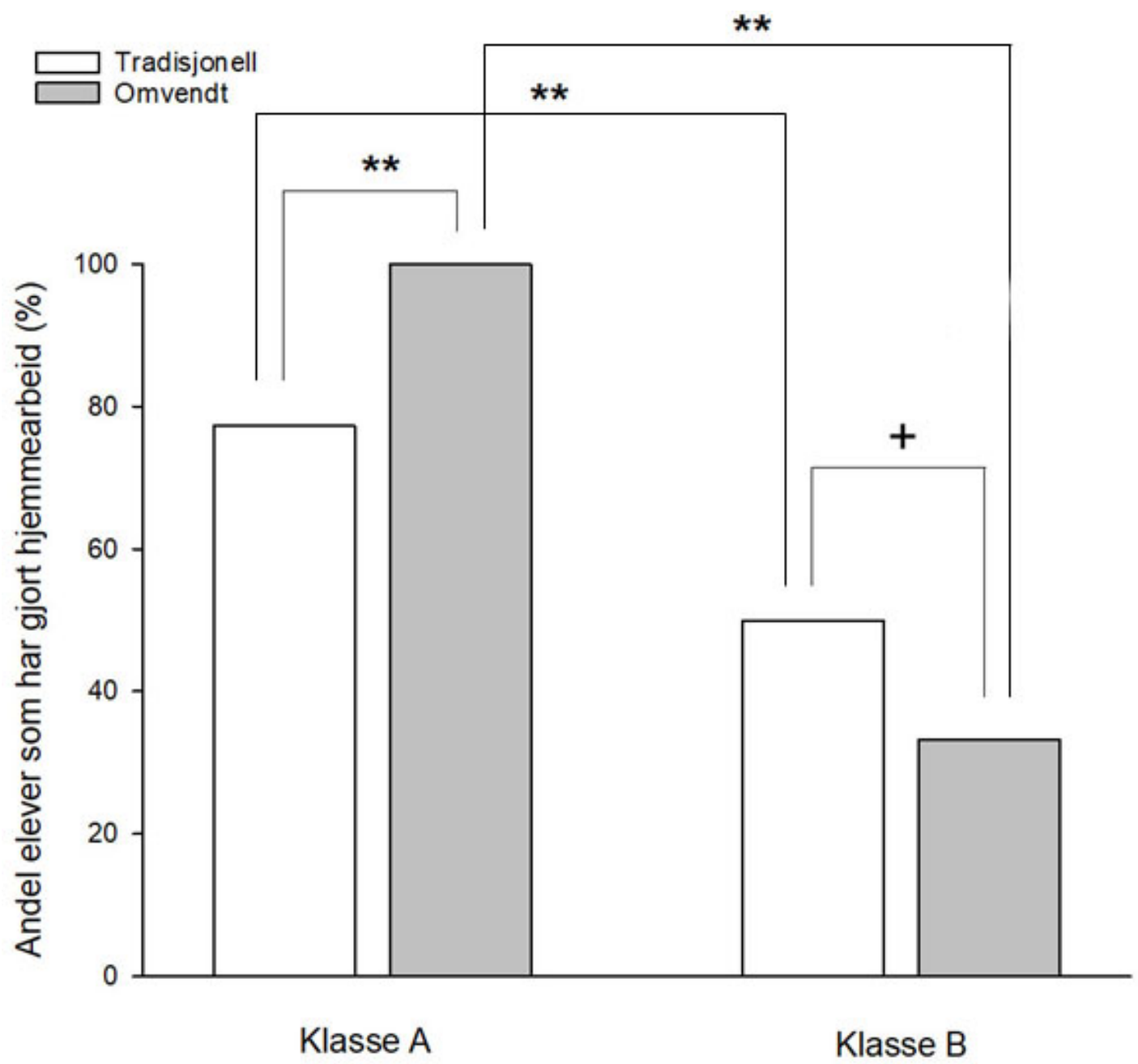

Figur 3. Andel elever i klasse A og klasse B som sa de gjorde hjemmearbeidet i forbindelse med tradisjonell og omvendt undervisning.

** $p<0.01,+p=0.074$; binomial test. 
På grunn av disse forskjellene ville vi også undersøke om klassene var forskjellige uavhengig av undervisningsmetode. Her fant vi at andelen elever som hadde gjort hjemmearbeidet i klasse A var høyere enn i klasse B ( $p<0.001$, vedlegg 9, tabell D). Dette gjaldt for både omvendt og tradisjonell undervisning (figur 3 , og vedlegg 9, tabell E og F).

En oppsummering av dette viser at andelen elever som forberedte seg til omvendt undervisning, ikke var signifikant forskjellig fra tradisjonell undervisning. Videobasert hjemmearbeid førte altså ikke til at flere elever forberedte seg til undervisning sammenlignet med tekstbasert hjemmearbeid. Imidlertid var det forskjeller mellom klassene. I klasse A var andelen elever som gjorde hjemmearbeid med omvendt undervisning høyere enn med tradisjonell undervisning, mens i klasse B var andelen elever som gjorde hjemmearbeid med tradisjonell undervisning høyere enn med omvendt undervisning. Klasse A hadde en totalt høyere andel elever som gjorde hjemmearbeidet med begge undervisningsmetodene.

\section{Betydningen av omvendt undervisning for elevenes motivasjon}

Det andre vi ønsket å finne ut, var hvilken betydning omvendt undervisning hadde for elevenes motivasjon. For å belyse dette analyserte og diskuterte vi vårt kvalitative datamateriale opp mot SDT. Den påstår at elever vil utvikle autonom motivasjon i læringsomgivelser som tilfredsstiller deres behov for kompetanse, autonomi og tilhørighet. Mangel på autonomi og kun en viss grad av kompetanse og tilhørighet vil derimot fremme utvikling av kontrollert motivasjon, mens manglende tilfredsstillelse av alle tre behovene fører til at motivasjon uteblir (Deci \& Ryan, 2008b). Vi søkte derfor etter utsagn som kunne si noe om hvorvidt disse tre behovene ble tilfredsstilt. I tillegg søkte vi etter utsagn som ga direkte uttrykk for autonom motivasjon. Dette resulterte i at elevenes utsagn ble delt inn i fire kategorier: 1) Kompetanse, 2) Tilhørighet, 3) Autonomi, og 4) Direkte uttrykk for autonom motivasjon (vedlegg 10). Informantene har vi kalt gA, jA, gB og jB, hvor første bokstav står for om det er gutt (g) eller jente (j) og andre bokstav står for klasse A eller B.

Behovet for kompetanse synes å bli tilfredsstilt med både omvendt og tradisjonell undervisning hos alle fire elevene som ble intervjuet. Det synes faktisk å være en generell oppfatning om at de lærte like mye av de to undervisningsmetodene. Dette kom til uttrykk i sjulæreboka forskjellige utsagn som ble bekreftet av tre eller alle fire elevene (vedlegg 10, tabell 1). For eksempel på spørsmålet om hvordan de opplevde at metoden hadde noe å si for hvor mye de lærte om temaet, svarte elevene: «Tror jeg lærte ca like mye» (jA). «Enig» (gA). «Ganske likt hvor mye vi lærte» (gB). «Ja» (jB).

Elevenes behov for tilhørighet synes derimot å bli tilfredsstilt bedre med omvendt enn med tradisjonell undervisning. Dette kom til uttrykk i fem forskjellige utsagn som ble bekreftet av to eller alle fire elevene (vedlegg 10, tabell 2). Et av utsagnene fremhever det å arbeide i gruppe sammen med andre elever 
som positivt: «Det var artig med oppgaver i gruppe» (jB). En annen type utsagn løfter frem opplevelsen av å være et «vi» i arbeidsprosessen: «Blir litt annerledes og nytt, og da engasjerer vi oss mer» (gA). Dette pronomenet ble brukt flere ganger selv om intervjuspørsmålene ble formulert med «du».

Elevenes behov for autonomi synes også å bli tilfredsstilt bedre med omvendt enn med tradisjonell undervisning, skjønt dette kom til uttrykk i kun to utsagn som ble bekreftet av henholdsvis én og to elever (vedlegg 10, tabell 3). Tre av elevene poengterte friheten metoden ga til å medvirke i egen læringsprosess, og to av dem relaterte denne medvirkningen til det praktiske arbeidet de utførte i den omvendte undervisningen på skolen: «Mer rom for å prøve ut ting. Og å gjøre det praktisk liksom» (jA og gA). «Lærte mye av filmen, og kunne jo bare sjekke boka dersom det var noe jeg glemte» $(\mathrm{jB})$.

En oppsummering av disse tre kategoriene indikerer at elevenes behov for kompetanse blir tilfredsstilt i like stor grad av omvendt som av tradisjonell undervisning, mens elevenes behov for tilhørighet og autonomi synes å bli tilfredsstilt bedre med omvendt undervisning. I lys av SDT indikerer dette at omvendt undervisning kan fremme elevenes autonome motivasjon bedre enn tradisjonell undervisning. Dette støttes av tolv utsagn i analysens 4 . kategori som gir direkte uttrykk for autonom motivasjon i forbindelse med omvendt undervisning (vedlegg 10, tabell 4), som for eksempel: «Fikk mer lyst til å lære av aktivitetene og videoen» (jA), «Enig» (gA), og «Mer morsomt med omvendt både hjemme og på skolen» (gB), «Ja» (jB). Disse utsagnene synes derfor å bekrefte resultatene fra analysen som ble gjort ved hjelp av SDT. Imidlertid må det påpekes at det var nyanseforskjeller mellom elevene i klasse A og B. Mens begge elevene i klasse A uttrykte seg utelukkende positivt til omvendt undervisning, var dette noe tvetydig hos elevene i klasse B. På spørsmålet om hvordan de opplevde at metoden hadde noe å si for hvor lyst de hadde til å jobbe i timen, svarte en av elevene følgende: «Bedre med tavle, fordi man kanskje ikke husket filmen» (gB). Her uttrykker eleven at omvendt undervisning ikke sikret ham tilgang på nødvendig informasjon mens han jobbet med oppgavene, noe han imidlertid opplevde at tradisjonell undervisning gjorde. Det ser derfor ut til at denne eleven i klasse B, til tross for at han viser større grad av autonom motivasjon for omvendt undervisning enn tradisjonell, likevel foretrekker elementer ved tradisjonell undervisning.

\section{Diskusjon}

Ut fra SDT og sosiokulturell læringsteori, forventet vi at omvendt undervisning skulle fremme autonom motivasjon, og dermed føre til at flere elever forberedte seg og mestret oppgavene på skolen, og følgelig oppnådde høyere læringsutbytte enn med tradisjonell undervisning. Med forbehold om at utvalget er lite, støtter våre funn påstanden til Abeysekara og Dawson (2015) om at omvendt undervisning fremmer elevenes autonome motivasjon mer enn tradisjonell undervisning. 
Imidlertid viser vår studie at effekten av omvendt undervisning på elevenes forberedelser og læringsutbytte ikke er signifikant forskjellig fra tradisjonell undervisning.

\section{Elevenes alder}

Selv om våre kvantitative funn tilsynelatende strider mot både teori og studier fra videregående skole (Chao et al., 2015; Huang \& Hong, 2016; Schultz et al., 2014) og høyere utdanning (Berg et al., 2015; Day \& Foley, 2006; Mason et al., 2013; McLaughlin et al., 2014; Missildine et al., 2013; Pierce \& Fox, 2012), er de i samsvar med studier fra ungdomskolen (Chen, 2016; Clark, 2015; Kirvan et al., 2015). Dette kan bety at elevenes alder har betydning for effekten av omvendt undervisning. I så fall kan det kanskje forklares med elevenes evne til selvregulering. Selvregulering er en ferdighet som utvikles over tid (Whitebread \& Basilio, 2011), og siden omvendt undervisning stiller større krav til selvregulering enn tradisjonell undervisning (Abeysekera \& Dawson, 2015; Chen, 2016; Mason et al., 2013), er det kanskje ikke overraskende at elever i høyere utdanning både forbereder seg bedre og har bedre læringsutbytte med omvendt undervisning enn elever i lavere utdanning. Imidlertid er det verd å nevne at både vår studie og andre studier fra ungdomsskolen fant numeriske forskjeller i læringsutbytte i favør av omvendt undervisning (Chen, 2016; Clark, 2015; Kirvan et al., 2015), noe som kan tyde på at denne metoden er bedre også i lavere utdanning, skjønt effekten er mindre enn i høyere utdanning.

\section{Omvendt undervisning kan påvirke ulike klasser forskjellig}

På grunn av at begge klassene ble testet med begge undervisningsmetodene, fikk vi også informasjon som viste at det spesielt var klasse B som syntes å bryte med våre teoribaserte forventninger, skjønt dette kun er basert på numeriske og ikke signifikante verdier. Dersom disse verdiene likevel har betydning, kan forklaringen være at elevene i klasse B trengte mer tid til å tilpasse seg den omvendte undervisningsmetoden enn elevene i klasse A, noe som støttes av studier som viser at tiden det tar å tilpasse seg metoden varierer mellom elever (Chen, 2016; Day \& Foley, 2006; Mason et al., 2013). Noen studenter synes til og med å foretrekke tradisjonell undervisning på mer permanent basis (Day \& Foley, 2006; McLaughlin et al., 2014; Missildine et al., 2013; Pierce \& Fox, 2012). I vår studie ble dette antydet av en av elevene i klasse B som syntes tavla var bedre fordi han kanskje ikke husket filmen. Utsagnet er knyttet til hjemmearbeidet som er den delen av undervisningen som krever sterkest selvregulering. Hjemmearbeidet er også den delen av undervisningen som er spesielt viktig i den omvendte metoden. Dette fordi metoden ikke legger opp til presentasjon av fagstoffet i klasserommet. Elever som stiller uforberedt til undervisningen, vil få problemer med å mestre gruppeoppgavene og dermed også sannsynligvis få redusert læringsutbytte. I tradisjonell undervisning får derimot elevene fagstoffet presentert i klasserommet uansett om de har gjort hjemmearbeidet eller ikke. Svakere selvregulering uttrykt 
i form av å stille uforberedt til tradisjonell undervisning vil derfor ikke få like store konsekvenser. At elevene i klasse B hadde svakere selvregulering, støttes av opplysninger vi fikk fra klassenes kontaktlærer om at det var mer uro i klasse B og at elevenes gjennomsnittlige standpunktkarakter fra 8. trinn var noe lavere enn i klasse A. Mens uro gjerne er et direkte tegn på lavere selvregulering, er prestasjoner et indirekte tegn. Ifølge Duckworth, Taxer, Eskreis-Winkler, Galla og Gross (2019) har akademiske prestasjoner en positiv sammenheng med selvregulering.

\section{Mulig sammenheng mellom elevenes forberedelse og læringsutbytte}

I vår studie ser det ut til at elevenes forberedelser i stor grad kan forklare elevenes læringsutbytte. Klasse A hadde for eksempel en signifikant større andel elever som forberedte seg enn klasse B, med begge metodene. De hadde også høyere læringsutbytte med begge metodene, skjønt denne forskjellen mellom klassene var signifikant kun i den omvendte undervisningen. Videre hadde klasse A en signifikant større andel elever som forberedte seg til omvendt undervisning enn til tradisjonell, og i tråd med dette hadde de også et numerisk høyere læringsutbytte med denne metoden sammenlignet med tradisjonell undervisning. Klasse B hadde en numerisk høyere andel elever som forberedte seg til tradisjonell undervisning, og i tråd med dette oppnådde de et numerisk høyere læringsutbytte med denne metoden. Det ser derfor ut til at forberedelsene er viktige for læringsutbyttet med begge undervisningsmetodene. Dette støttes av studier som viser positiv sammenheng mellom hjemmearbeid og akademiske prestasjoner (Cooper, Robinson \& Patall, 2006; Núñez, Suárez, Rosário, Vallejo, Cerezo \& Valle, 2015).

\section{Begrensninger i studien}

Til tross for at vårt funn om likt læringsutbytte mellom omvendt og tradisjonell undervisning har støtte i tidligere forskning på elever i ungdomsskolen (Chen, 2016; Clark, 2015; Kirvan et al., 2015), er det fortsatt noen begrensninger som vanskeliggjør en evidensbasert konklusjon. For det første er vårt utvalg på 46 elever lite. Små utvalg reduserer generelt sannsynligheten for å finne signifikante forskjeller. Det lave antallet elever både i vår studie og i de tre andre studiene fra ungdomsskolen (mellom 42 og 64) (Chen, 2016; Clark, 2015; Kirvan et al., 2015), sammenlignet med videregående (mellom 61 og 91) (Chao et al., 2015; Huang \& Hong, 2016; Schultz et al., 2014) og høyere utdanning (mellom 40 og 598) (Berg et al., 2015; Day \& Foley, 2006; Mason et al., 2013; McLaughlin et al., 2014; Missildine et al., 2013; Pierce \& Fox, 2012), kan derfor også bidra til å forklare hvorfor elever i ungdomsskolen ikke synes å oppnå et signifikant høyere læringsutbytte med omvendt undervisning enn med tradisjonell.

Noe av forklaringen på manglende signifikante forskjeller kan også ligge i studiens design. Klassene fikk for eksempel kun erfare én økt med omvendt undervisning, og denne økten startet med hjemmearbeid. Dette betyr at selv om 
omvendt undervisning fremmer elevenes autonome motivasjon og følgelig kanskje stimulerer til økt forberedelse, vil ikke dette skje før en eventuell andre $ø$ kt. Elevene må erfare metoden for å utvikle autonom motivasjon. På grunn av at vår studie kun besto av én økt, kunne vi bare undersøke hvorvidt informasjon om at hjemmearbeidet var video kunne bidra til at flere elever forberedte seg, noe vi fant at det ikke gjorde. At én økt kan være utilstrekkelig, støttes av studier som viser at noen elever/studenter trenger tid til å tilpasse seg metoden (Chen, 2016; Day \& Foley, 2006; Mason et al., 2013). I Chen (2016), for eksempel, kom mange av elevene uforberedt til undervisning den første av de tre ukene studien pågikk. De hadde derfor vanskelig for å delta i klasseromsaktivitetene, og elevenes læringsutbytte var ikke signifikant forskjellig mellom omvendt og tradisjonell undervisning.

Andre forklaringer på manglende signifikante forskjeller i henhold til våre forventninger kan ligge i designen av undervisningsmetodene som ble brukt i denne studien. Slike argumenter vil imidlertid innebære at definisjonen av omvendt undervisning i Bishop og Verleger (2013) ikke er tilstrekkelig spesifisert. Definisjonen sier for eksempel ingen ting om antall elever per gruppe eller varigheten til de ulike aktivitetene i klasserommet, hverken totalt eller hver for seg. I vår studie var det fire til fem elever per gruppe. Imidlertid ville det kanskje vært bedre med færre elever, spesielt i forbindelse med oppgavene som var knyttet til fysiske modeller, eller hvor elevene hadde ulike roller. Færre elever ville økt sannsynligheten for at alle fikk god tid med modellene og med å spille de ulike rollene. Videre varte gruppeaktivitetene totalt 35 minutter og hver oppgave sju minutter. Dette er kanskje for kort tid til at alle de fire til fem elevene i hver gruppe fikk satt seg godt inn i oppgavene, diskutert godt med hverandre og med læreren, sjekket opp i litteratur, og utført de praktiske oppgavene. Uttalelsen om mangel på tilstrekkelig informasjon hos en av elevene som ble intervjuet kan kanskje også være et uttrykk for mangel på tid.

En annen forklaring kan ligge i at vi brukte flervalgsspørsmål (pre-/posttest) som gir begrenset med informasjon om hvor mye elevene faktisk har lært. Dette til tross for at slike tester er vanlige i både forskningssammenheng og i eksamenssammenheng ved universiteter og høgskoler . Videre intervjuet vi kun fire elever, noe som ikke nødvendigvis gir en riktig representasjon av klassene til tross for utvalgskriteriene. I tillegg utførte vi intervjuet i gruppe, noe som kan ha ført til at elevene ble påvirket av hverandre. At samme person utførte både undervisning og intervju, kan også ha påvirket elevenes svar, men siden personen underviste med begge undervisningsmetodene uten noe forsøk på å fremme den ene metoden fremfor den andre, anså vi problemet som lite. At undervisningen ble utført av en person fra forskerteamet, og ikke av elevenes egen lærer, er en annen mulig svakhet med studien. Grunnen til dette er at lærerens betydning for elevenes læring kan være forskjellig med de to undervisningsmetodene. Spesielt i omvendt undervisning, hvor læreren i større grad enn i tradisjonell undervisning er en diskusjonspartner, kan det kanskje være en fordel at elevene kjenner læreren. Det samme 
gjelder videoene, men hvorvidt disse antakelsene faktisk har betydning, må avklares i fremtidige studier. At tema var forskjellig for de to undervisningsmetodene, er også en svakhet med studien. Selv om temaene inneholdt ulike fagbegrep og at antall fagbegrep var omtrent likt, kan man likevel ikke være sikker på at temaene er like vanskelige. Imidlertid er dette en uunngåelig begrensning med den kvasieksperimentelle metoden. Videre viste resultatene at forkunnskapene om de ulike temaene var forskjellige. Selv om dette ikke nødvendigvis sier noe om hvor vanskelig et tema er, kan det kanskje påvirke læringsutbyttet.

\section{Konklusjon}

Til tross for at vår studie har benyttet et begrenset utvalg elever og metoder for å undersøke grunnleggende fenomener som motivasjon og læring, mener vi at funnene likevel gir nyttige bidrag til eksisterende empiri som sier noe om hvordan omvendt undervisning påvirker elevers motivasjon, forberedelser og læringsutbytte i forhold til tradisjonell metode.

Vår studie indikerer at en økt med omvendt undervisning i ungdomsskolen kan fremme autonom motivasjon bedre enn tradisjonell undervisning. Imidlertid bidrar det ikke nødvendigvis til at flere elever forbereder seg eller oppnår høyere læringsutbytte, skjønt undervisningsmetoden kan påvirke ulike elever forskjellig. Videre er det indikasjoner på at forberedelser har vesentlig betydning for læringsutbyttet i både omvendt og tradisjonell undervisning.

For forskere og lærere i skolen som ønsker å prøve ut omvendt undervisning i håp om bedre effekt enn tradisjonell undervisning, indikerer vår studie at de minimum bør gjennomføre to økter, men helst flere siden det tar tid å tilpasse seg metoden, og denne tiden synes å variere mellom elever. I tillegg kan det være en god ide å foreta tiltak som øker sjansen for at elevene forbereder seg, siden forberedelser synes å være viktige for læringsutbyttet. Spesielt til første undervisningsøkt er dette viktig siden informasjon alene om at hjemmearbeidet er video, ikke synes å være tilstrekkelig for å motivere elevene. Når det gjelder aktivitetene i klasserommet kan det være en god ide å redusere gruppestørrelsen for å øke sjansen for at alle elevene får nok tid til en grundig involvering i og gjennomføring av oppgavene.

På grunn av stor entusiasme for den omvendte undervisningsmetoden i senere tid er det viktig å dokumentere effekten av metoden. Siden slik dokumentasjon er mangelfull, spesielt i ungdomsskolen, mener vi at resultatene fra denne mindre studien, samt begrensningene vi har belyst, er spesielt viktige for å danne et grunnlag for undersøkelser i større skala og gjerne med lengre intervensjonstid. 


\section{Om forfatterne}

Pål Kvello er førsteamanuensis ved Norges teknisk-naturvitenskapelige universitet (NTNU). Hans forskningsinteresser omfatter blant annet nevrobiologi, både som fagforskning og som tema i didaktisk forskning med spesielt fokus på bruk av den omvendte undervisningsmetoden.

Institusjonstilknytning: Institutt for lærerutdanning, NTNU, 7491 Trondheim. E-post: pal.kvello@ntnu.no

Stine Slaatsveen Barstad er grunnskolelærer (adjunkt). Institusjonstilknytning: Institutt for lærerutdanning, NTNU, 7491 Trondheim. E-post: StineSBarstad@gmail.com

Bernt Rønning er førsteamanuensis ved Norges teknisk-naturvitenskapelige universitet (NTNU). Hans forskningsinteresser omfatter blant annet evolusjonsbiologi med særlig vekt på populasjonsgenetikk og evolusjonsfysiologi hos virveldyr.

Institusjonstilknytning: Institutt for lærerutdanning, NTNU, 7491 Trondheim. E-post: bernt.ronning@ntnu.no

Elin Tronsaune Moen er universitetslektor ved Norges teknisk-naturvitenskapelige universitet (NTNU). Hennes forskningsinteresser omfatter blant annet læring hos barn med særlig vekt på læringsmiljø, selvregulert læring, motivasjon og selvoppfatning.

Institusjonstilknytning: Institutt for lærerutdanning, NTNU, 7491 Trondheim. E-post: elin.moen@ntnu.no

Ove Østerlie er universitetslektor ved Norges teknisk-naturvitenskapelige universitet (NTNU). Hans forskningsinteresser omfatter blant annet didaktikk og undervisningsmetoder i kroppsøving med spesialitet i flippet læring og kroppsøving som inkluderingsarena.

Institusjonstilknytning: Institutt for lærerutdanning, NTNU, 7491 Trondheim. E-post: ove.osterlie@ntnu.no 


\section{Referanser}

Abeysekera, L. \& Dawson, P. (2015). Motivation and cognitive load in the flipped classroom: definition, rationale and a call for research. Higher Education Research \& Development, 34(1), 1-14. doi: https://doi.org/10.1080/07294360.2014.934336

Berg, A., Ibrahim, H., Magaster, S. \& Salbod, S. (2015). Flipping over the flipped classroom. Contemporary Issues in Communication Science and Disorders, 42, 16-25.

Bishop, J. L. \& Verleger, M. A. (2013). The flipped classroom: A survey of the research. Paper presented at the ASEE National Conference Proceedings, Atlanta, GA.

Chao, C.-Y., Chen, Y.-T. \& Chuang, K.-Y. (2015). Exploring students' learning attitude and achievement in flipped learning supported computer aided design curriculum: A study in high school engineering education. Computer Applications in Engineering Education, 23(4), 514-526. doi: https://doi.org/10.1002/cae.21622

Chen, F., Lui, A. M. \& Martinelli, S. M. (2017). A systematic review of the effectiveness of flipped classrooms in medical education. Medical Education, 51(6), 585-597. doi: https://doi.org/10.1111/medu.13272

Chen, K.-S., Monrouxe, L., Lu, Y.-H., Jenq, C.-C., Chang, Y.-J., Chang, Y.-C. \& Chai, P. Y.C. (2018). Academic outcomes of flipped classroom learning: a metaanalysis. Medical Education, 52(9), 910-924. doi: https://doi.org/10.1111/medu.13616

Chen, L.-L. (2016). Impacts of flipped classroom in high school health education. Journal of Educational Technology Systems, 44(4), 411-420. doi: https://doi.org/10.1177/0047239515626371

Cheng, L., Ritzhaupt, A. D. \& Antonenko, P. (2019). Effects of the flipped classroom instructional strategy on students' learning outcomes: a meta-analysis. Education Technology Research and Development, 67(4), 793-824. doi: https://doi.org/10.1007/s11423-018-9633-7

Clark, K. R. (2015). The effects of the flipped model of instruction on student engagement and performance in the secondary mathematics classroom. Journal of Educators Online, 12(1), 91-115.

Cohen, J. (1992). A power primer. Psychological Bulletin, 112(1), 155-159.

Cooper, H., Robinson, J. C. \& Patall, E. A. (2006). Does homework improve academic achievement? A synthesis of research, 1987-2003. Review of Educational Research, 76(1), 1-62.

Day, J. A. \& Foley, J. D. (2006). Evaluating a web lecture intervention in a human-computer interaction course. IEEE Transactions on Education, 49(4), 420-431. doi: https://doi.org/10.1109/TE.2006.879792

Deci, E. L. \& Ryan, R. M. (2008a). Facilitating optimal motivation and psychological wellbeing across life's domains. Canadian Psychology/Psychologie Canadienne, 49(1), 1423. doi: https://doi.org/10.1037/0708-5591.49.1.14

Deci, E. L. \& Ryan, R. M. (2008b). Self-determination theory: A macrotheory of human motivation, development, and health. Canadian Psychology/Psychologie Canadienne, 49(3), 182-185. doi: https://doi.org/10.1037/a0012801

Duckworth, A. L., Taxer, J. L., Eskreis-Winkler, L., Galla, B. M. \& Gross, J. J. (2019). Selfcontrol and academic achievement. Annual Review of Psychology, 70, 373-399. doi: https://doi.org/10.1146/annurev-psych-010418-103230

Freeman, S., Eddy, S. L., McDonough, M, Smith, M. K., Okoroafor, N., Jordt, H. \& Wenderoth, M. P. (2014). Active learning increases student performance in science, engineering, and mathematics. PNAS, 111(23), 8410-8415. doi: https://doi.org/10.1073/pnas.1319030111 
Gauci, S. A., Dantas, A. M., Williams, D. A. \& Kemm, R. E. (2009). Promoting studentcentered active learning in lectures with a personal response system. Advances in Physiology Education, 33(1), 60-71. doi: https://doi.org/10.1152/advan.00109.2007

Gillette, C., Rudolph, M., Kimble, C., Rockich-Winston, N., Smith, L. \& Broedel-Zaugg, K. (2018). A meta-analysis of outcomes comparing flipped classroom and lecture. American Journal of Pharmaceutical Education, 82(5), 433-440.

Hagger, M. S., Hardcastle, S. J., Chater, A., Mallett, C., Pal, S. \& Chatzisarantis, N. L. D. (2014). Autonomous and controlled motivational regulations for multiple health-related behaviors: between- and within-participants analyses. Health Psychology \& Behavioral Medicine, 2(1), 565-601. doi: https://doi.org/10.1080/21642850.2014.912945

Hall, A. A. \& DuFrene, D. D. (2016). Best practices for launching a flipped classroom. Business and Professional Communication Quarterly, 79(2), 234-242. doi: https://doi.org/10.1177/2329490615606733

Hannisdal, M., Haugan, J. \& Munkvik, M. (2007). Eureka 9. Oslo: Gyldendal.

Hattie, J. (2012). Visible learning for teachers: Maximizing impact on learning. London and New York: Routledge, Taylor \& Francis Group.

Holter, H. (1996). Fra kvalitative metoder til kvalitativ samfunnsforskning. I H. Holter \& R. Kalleberg (red.), Kvalitative metoder i samfunnsforskning (s. 9-25). Oslo: Universitetsforlaget.

Hu, R., Gao, H., Ye, Y., Ni, Z., Jiang, N. \& Jiang, X. (2018). Effectiveness of flipped classrooms in Chinese baccalaureate nursing education: A meta-analysis of randomized controlled trials. International Journal of Nursing Studies, 79, 94-103. doi: https://doi.org/10.1016/j.ijnurstu.2017.11.012

Huang, Y.-N. \& Hong, Z.-R. (2016). The effects of a flipped English classroom intervention on students' information and communication technology and English reading comprehension. Educational Technology Research and Development, 64, 175-193. doi: https://doi.org/10.1007/s11423-015-9412-7

Kim, M. K., Kim, S. M., Khera, O. \& Getman, J. (2014). The experience of three flipped classrooms in an urban university: an exploration of design principles. The Internet and Higher Education, 22, 37-50. doi: https://doi.org/10.1016/j.iheduc.2014.04.003

Kirvan, R., Rakes, C. R. \& Zamora, R. (2015). Flipping an algebra classroom: Analyzing, modeling, and solving systems of linear equations. Computers in the Schools. Interdisiplinary Journal of Practice, Theory, and Applied Research, 32(3-4), 201-223. doi: https://doi.org/10.1080/07380569.2015.1093902

Krumsvik, R. J. \& Jones, L. Ø. (2016). Flipped classroom i naturfag - Finnes det en sammenheng mellom omvendt undervisning (flipped classroom) og elevprestasjoner i naturfag? Norsk pedagogisk tidsskrift, 100(01), 61-73. doi: https://doi.org/10.18261/issn.1504-2987-2016-01-07

Kvernmo, G. (2010). Intervju som metode - barn/unge som informanter. I E. Arntzen \& J. Tolsby (red.), Studenten som forsker i utdanning og yrke. Vitenskapelig tenkning og metodebruk (s. 66-80). Høgskolen i Akershus.

Lage, M. J., Platt, G. J. \& Treglia, M. (2000). Inverting the classroom: A gateway to creating an inclusive learning environment. The Journal of Economic Education, 31(1), 30-43.

Lo, C. K. \& Hew, K. F. (2017). A critical review of flipped classroom challenges in K-12 education: Possible solutions and recommendations for future research. Research and Practice in Technology Enhanced Learning, 12, Art. 4. doi: https://doi.org/10.1186/s41039-016-0044-2 
Mason, G. S., Shuman, T. R. \& Cook, K. E. (2013). Comparing the effectiveness of an inverted classroom to a traditional classroom in an upper-division engineering course. IEEE Transactions on education, 56(4), 430-435. doi: https://doi.org/10.1109/TE.2013.2249066

McLaughlin, J. E., Roth, M. T., Glatt, D. M., Gharkholonarehe, N., Davidson, C. A., Griffin, L. M., Esserman, D. A. \& Mumper, R. J. (2014). The flipped classroom: A course redesign to foster learning and engagement in a health professions school. Academic Medicine, 89(2), 236-243. doi: https://doi.org/10.1097/ACM.0000000000000086

Missildine, K., Fountain, R., Summers, L. \& Gosselin, K. (2013). Flipping the classroom to improve student performance and satisfaction. Journal of Nursing Education, 52(10), 597-599. doi: https://doi.org/10.3928/01484834-20130919-03

Nilssen, V. (2012). Analyse i kvalitative studier. Den skrivende forskeren. Oslo: Universitetsforlaget.

Núñez, J. C., Suárez, N., Rosário, P., Vallejo, G., Cerezo, R. \& Valle, A. (2015). Teachers’ feedback on homework, homework-related behaviors, and academic achievement. The Journal of Educational Research, 108(3), 204-216. doi: https://doi.org/10.1080/00220671.2013.878298

Pierce, R. \& Fox, J. (2012). Instructional design and assessment. Vodcasts and active-learning exercises in a "flipped classroom" model of renal pharmacotherapy module. American Journal of Pharmaceutical Education 76(10), 1-5.

Prince, M. (2004). Does active learning work? A review of the research. Journal of Engineering Education, 93(3), 223-231.

Schultz, D., Duffield, S., Rasmussen, S. C. \& Wageman, J. (2014). Effects of the flipped classroom model on student performance for advanced placement high school chemistry students. Journal of Chemical Education, 91(9), 1334-1339. doi: https://doi.org/10.1021/ed400868x

Shadish, W. R., Cook, T. D. \& Campbell, D. T. (2002). Experimental and quasi-experimental designs for generalized causal inference. Boston, New York: Houghton Mifflin Company.

Telhaug, A. O. \& Mediås, O. A. (2003). Grunnskolen som nasjonsbygger: fra statspietisme til nyliberalisme. Oslo: Abstrakt forlag AS.

Thaman, R., Dhillon, S., Saggar, S., Gupta, M. \& Kaur, H. (2013). Promoting active learning in respiratory physiology - positive student perception and improved outcomes. National Journal of Physiology, Pharmacy \& Pharmacology, 3(1), 27-34.

Vygotsky, L. S. (1978). Mind in society. The development of higher psychological processes. Cambridge, MA: Harvard Univ. Press.

Whitebread, D. \& Basilio, M. (2011). The emergency and early development of selfregulation in young children. Profesorado. Revista de Curriculum y Formacion del Profesorado, 16(1), 15-33. 


\section{Vedlegg 1}

Spørsmål til intervju

1) Hvordan opplever du at metoden(e) hadde noe å si for hvor lyst du hadde til å jobbe i timen?

2) Hvordan opplever du at metoden(e) hadde noe å si for hvor lenge du hadde lyst til å jobbe med aktiviteten?

3) Hvordan opplever du at metoden(e) hadde noe å si for hvor mye du lærte om temaet?

4) Hvordan opplever du at metoden(e) hadde noe å si for hvor mye du fikk medvirke i arbeidet? (Her tenker jeg fokus på elevmedvirkning og selvregulering, ev. strategibruk.)

5) Hvordan opplever du at metoden(e) bidro til at du mestret oppgavene du gjorde på skolen?

Spørsmålene er ment som forslag eller utgangspunkt for samtale med elevene i etterkant av testene. Jeg ser også for meg at det vil være naturlig med oppfølgingsspørsmål under hvert hovedspørsmål, som særlig går på å få eleven(e) til å utdype. Det vil for eksempel være naturlig å spørre «hvorfor» ev. «hvorfor ikke». 


\section{Vedlegg 2: \\ Kunnskapstest}

\section{Lys og synssansen}

Sett kryss ved riktig svaralternativ. Det er kun ett riktig svar på hvert spørsmål.

\section{Hva skjer med lyset når det treffer hornhinnen?}
a. Lyset brytes slik at lysstrålene fra gjenstander vi ser på, samles på netthinnen bak i øyet
b. Lyset spres slik at lysstrålene fra gjenstander vi ser på, spres utover hele netthinnen
c. Lyset blir absorbert
d. Lyset reflekteres slik at andre kan se det samme som du ser

\section{Hvilke to typer sanseceller reagerer på lys i netthinnen?}
a. Blå og brun
b. Staver og tapper
c. Gule og røde
d. Staver og grafer

3. Hva gjør konkave linser med lyset?
a. De sprer lyset
b. De reflekterer lyset
c. De absorberer lyset
d. De samler lyset

4. Hvordan kan vi bruke linsen til å endre lysstrålenes brennpunkt?
a. Vi kan ved hjelp av muskler i øyet flytte linsen frem og tilbake i øyet
b. Vi kan ved hjelp av muskler i øyet flytte linsen opp og ned i øyet
c. Vi kan ved hjelp av muskler i øyet endre formen på linsen slik at den blir lengre
d. Vi kan ved hjelp av muskler i øyet rotere linsen slik at oversiden peker ned og undersiden peker opp

5. Hvor er lysets brennpunkt hos nærsynte?
a. Foran netthinnen
b. Ovenfor netthinnen
c. Bak netthinnen
d. Under netthinnen

6. Hva er den vanligste årsaken til at man blir langsynt når man blir eldre?
a. Hjernen bruker mindre energi på synssansen
b. Øyet blir større så lyset blir mer spredt
c. Linsen blir mykere
d. Linsen blir stivere

7. Hva er karakteristisk for den gule flekken?
a. At sansecellene der er veldig store
b. At den ser grønn ut, ikke gul
c. At det ikke finnes sanseceller der
d. At det er veldig mange sanseceller der 
8. Hvorfor kan man ikke se lys som treffer den blinde flekken?
a. Fordi det ikke er noen sanseceller der
b. Fordi det er for mange sanseceller der
c. Fordi man alltid lukker øynene når lyset treffer den
d. Fordi lyset reflekteres der

9. Hvorfor ser vi ikke farger så godt når det er lite lys?
a. Fordi vi ikke kan se noe når det er lite lys
b. Fordi stavene, som gir oss fargesyn, ikke fungerer når det er lite lys
c. Fordi tappene, som gir oss fargesyn, ikke fungerer når det er lite lys
d. Fordi intensiteten av farget lys blir mye lavere enn hvitt lys

10. Hva er den vanligste årsaken til at noen personer er fargeblinde?
a. Personen mangler stavene som registrerer gult og grønt
b. Personen mangler alle stavene
c. Personen mangler alle tappene
d. Personen mangler tappene som registrerer rødt eller grønt

\section{Hormoner}

Sett kryss ved riktig svaralternativ. Det er kun ett riktig svar på hvert spørsmål.

\section{Hva er en kjertel?}
a. Samling av celler som produserer hormoner
b. En gruppe nerveceller
c. Stoffer som transporteres med blodet
d. Samling av celler som mottar hormoner

\section{Hvilken oppgave har hypofysen?}
a. Den produserer hormonet insulin
b. Den flyter rundt i blodet
c. Den produserer hormoner som får andre kjertler til å lage sine spesielle hormoner
d. Den produserer kjertler som får andre hormoner til å lage sine spesielle kjertler

\section{Hvor produseres hormonet insulin?}
a. Bukspyttkjertelen
b. Skjoldbruskkjertelen
c. Binyrene
d. Testiklene

\section{Hva skjer med kroppen når mye adrenalin skilles ut i blodet?}
a. Man blir sulten
b. Kroppen vokser
c. Pulsen øker
d. Kjønnsorganene modnes

\section{Hva er et hormon?}
a. Et signalstoff som sendes ut av cellene og fraktes i blodet
b. Et næringsstoff man må spise mye av for å komme i puberteten
c. En form for sukker som styrer sultfølelsen
d. Små organismer som lever i kroppen vår 
6. Hvordan fraktes hormonene rundt i kroppen?
a. Med elektriske impulser
b. Med blodet
c. Med tarmen
d. Med lymfesystemet

7. I hvilke situasjoner skilles adrenalin ut i blodet?
a. Når man er i fare
b. Når man koser seg
c. Etter at man har spist
d. Når man er trøtt

\section{Hvilke celler virker et hormon på?}
a. Et hormon virker på alle celler
b. Det er tilfeldig hvilke celler hormoner virker på
c. Et hormon virker bare på celler som har en bestemt lås
d. Et hormon virker ikke på celler

9. Hvorfor er det vanskelig å lure en løgndetektortest?
a. Fordi man ikke kan holde pusten lenge nok
b. Fordi belønningssystemet aktiveres
c. Fordi insulin hjelper druesukker inn i cellene
d. Fordi man ikke kan styre adrenalinnivået i kroppen

10. Hva heter hormonenes "Sjefs-kjertel”?
a. Testikkel
b. Hypofysen
c. Hjernebarken
d. Binyre 


\section{Vedlegg 3}

\section{Sammenheng mellom kunnskapstesten og de ulike delene av undervisningen}

Tabellene viser hvilke deler av undervisningene (omvendt og tradisjonell) som bidrar med svar på de ulike spørsmålene på kunnskapstesten. Ja = bidrar direkte, Nei = bidrar ikke, Indirekte = svaret er ikke gitt eksplisitt, men informasjonen er nok til at elevene bør kunne resonnere seg frem til svaret. (F.eks. i gruppeoppgavene om syn, lærer elevene at staver gir svart-hvitt syn og tappene gir fargesyn. Da bør elevene kunne svare riktig på spørsmål 9 om syn).

\section{Syn}

\begin{tabular}{|l|l|l|l|l|l|l|}
\hline $\begin{array}{l}\text { Spørsmål } \\
\text { kunn- } \\
\text { skapstest }\end{array}$ & $\begin{array}{l}\text { Omvendt undervisning } \\
\text { Video- } \\
\text { lekse }\end{array}$ & $\begin{array}{l}\text { Gruppe- } \\
\text { oppgaver }\end{array}$ & Lese-lekse & $\begin{array}{l}\text { Tavleunder- } \\
\text { visning }\end{array}$ & $\begin{array}{l}\text { Individuelle } \\
\text { oppgaver }\end{array}$ & $\begin{array}{l}\text { Opp- } \\
\text { summerings- } \\
\text { spørsmål }\end{array}$ \\
\hline 1 & Ja & Ja & Ja & Ja & Indirekte & Indirekte \\
\hline 2 & Ja & Ja & Ja & Ja & Ja & Ja \\
\hline 3 & Ja & Ja & Ja & Ja & Indirekte & Ja \\
\hline 4 & Ja & Ja & Ja & Ja & Indirekte & Ja \\
\hline 5 & Ja & Ja & Ja & Ja & Ja & Indirekte \\
\hline 6 & Nei & Ja & Ja & Nei & Nei & Ja \\
\hline 7 & Ja & Ja & Ja & Ja & Ja & Ja \\
\hline 8 & Nei & Ja & Ja & Nei & Nei & Ja \\
\hline 9 & Ja & Indirekte & Ja & Ja & Ja & Nei \\
\hline 10 & Nei* & Ja & Ja & Nei & Nei & Ja \\
\hline
\end{tabular}

*Svaret på spørsmål 10 om syn fikk de i filmsnutt som var en del av gruppeoppgavene.

\section{Hormoner}

\begin{tabular}{|c|c|c|c|c|c|c|}
\hline \multirow{2}{*}{$\begin{array}{l}\text { Spørsmål } \\
\text { kunn- } \\
\text { skapstest }\end{array}$} & \multicolumn{2}{|c|}{ Omvendt undervisning } & \multicolumn{3}{|c|}{ Tradisjonell undervisning } & \multirow{2}{*}{$\begin{array}{l}\text { Oppsummerings- } \\
\text { spørsmål }\end{array}$} \\
\hline & $\begin{array}{l}\text { Video- } \\
\text { lekse }\end{array}$ & $\begin{array}{l}\text { Gruppe- } \\
\text { oppgaver }\end{array}$ & $\begin{array}{l}\text { Lese- } \\
\text { lekse }\end{array}$ & $\begin{array}{l}\text { Tavleunder- } \\
\text { visning }\end{array}$ & $\begin{array}{l}\text { Individuelle } \\
\text { oppgaver }\end{array}$ & \\
\hline 1 & Ja & $\mathrm{Ja}$ & Ja & $\mathrm{Ja}$ & $\mathrm{Ja}$ & Indirekte \\
\hline 2 & $\mathrm{Ja}$ & Indirekte & Ja & $\mathrm{Ja}$ & $\mathrm{Ja}$ & Ja \\
\hline 3 & Nei & $\mathrm{Ja}$ & Ja & Nei & Nei & $\mathrm{Ja}$ \\
\hline 4 & $\mathrm{Ja}$ & $\mathrm{Ja}$ & Ja & $\mathrm{Ja}$ & Ja & $\mathrm{Ja}$ \\
\hline 5 & $\mathrm{Ja}$ & Indirekte & Ja & Ja & Indirekte & Indirekte \\
\hline 6 & $\mathrm{Ja}$ & Nei & Ja & Ja & Indirekte & $\mathrm{Ja}$ \\
\hline 7 & Ja & Ja & Ja & Ja & Ja & Ja \\
\hline 8 & $\mathrm{Ja}$ & Indirekte & Ja & $\mathrm{Ja}$ & Nei & Nei \\
\hline 9 & $\mathrm{Ja}$ & $\mathrm{Ja}$ & Ja & $\mathrm{Ja}$ & Nei & Indirekte \\
\hline 10 & $\mathrm{Ja}$ & Indirekte & $\mathrm{Ja}$ & $\mathrm{Ja}$ & $\mathrm{Ja}$ & $\mathrm{Ja}$ \\
\hline
\end{tabular}




\section{Vedlegg 4:}

\section{Beskrivelse av gruppeoppgavene i klasserommet ved omvendt undervisning}

Tabell 1. Beskrivelse av gruppeoppgavene i klasserommet ved omvendt undervisning om temaet syn

\begin{tabular}{|l|l|}
\hline $\mathbf{N r}$ & Oppgave \\
\hline 1 & $\begin{array}{l}\text { Anatomisk modell av øyet. Elevene skulle bli enige om navnet på angitte deler og skrive det } \\
\text { ned på papir. }\end{array}$ \\
\hline 2 & $\begin{array}{l}\text { Modell av øyets linse. Oppgaver knyttet til sammenhengen mellom linsens form og lysets } \\
\text { brennpunkt. }\end{array}$ \\
\hline 3 & $\begin{array}{l}\text { Elevene skulle plassere et objekt på et angitt sted i synsfeltet (slik at det havnet i den blinde } \\
\text { flekk). De skulle så beskrive hva som skjedde og diskutere/forklare hvorfor. }\end{array}$ \\
\hline 4 & $\begin{array}{l}\text { Modell av en konveks og en konkav linse. Oppgaver knyttet til hvordan briller endrer } \\
\text { plasseringen av brennpunktet i øyet. }\end{array}$ \\
\hline 5 & $\begin{array}{l}\text { Filmsnutt (2,5 min) om fargeblindhet. Oppgaver knyttet til staver, tapper, farger og } \\
\text { fargeblindhet. }\end{array}$ \\
\hline
\end{tabular}

Tabell 2. Beskrivelse av gruppeoppgavene i klasserommet ved omvendt undervisning om temaet hormoner

\begin{tabular}{|l|l|}
\hline $\mathbf{N r}$ & Oppgave \\
\hline 1 & $\begin{array}{l}\text { Anatomisk modell av menneskekroppen med kjertler. Oppgaver knyttet til navn og } \\
\text { plassering av kjertler. }\end{array}$ \\
\hline 2 & $\begin{array}{l}\text { Elevene fikk oppgitt et utvalg navn på hormoner og kjertler. De skulle bli enige om hvilket } \\
\text { hormon og hvilken kjertel som hører sammen. }\end{array}$ \\
\hline 3 & $\begin{array}{l}\text { Elevene skulle gi eksempler på tilstander som er forbundet med utskillelse av adrenalin og } \\
\text { beskrive disse tilstandene til hverandre. }\end{array}$ \\
\hline 4 & $\begin{array}{l}\text { Løgndetektortest. En elev spurte, en annen svarte, sant eller usant. De andre elevene gjettet } \\
\text { om eleven løy eller ikke basert på deres observasjon av kroppens tilstand (tegn på adrenalin). }\end{array}$ \\
\hline 5 & $\begin{array}{l}\text { Fem påstander om hormoner hvor elevene skulle diskutere seg frem til om påstandene var } \\
\text { riktige eller feil. }\end{array}$ \\
\hline
\end{tabular}




\section{Vedlegg 5}

\section{Oppsummeringsspørsmål}

\section{Spørsmål om syn}

1. Hva er den gule flekken og hva er den blinde flekken?

2. Hva er tapper og hva er staver?

3. Hva er konveks linse og hva er konkav linse?

4. Hva er fargeblindhet?

5. Hvorfor bruker man sjelden røde fotballer?

6. Hva skjer i øyet når vi fokuserer?

7. Hva er et optisk brennpunkt?

8. Hvorfor er det så mange eldre som har behov for briller?

\section{Spørsmål om hormoner}

1. Hvor i kroppen produseres hormoner?

2. Hvordan fungerer en løgndetektor?

3. Hvordan fraktes hormonene rundt i kroppen?

4. Hva er hypofyse?

5. Hva er insulin og hvor produseres det?

6. Hvilke hormoner produseres i hvilke kjertler?

7. Hvordan virker adrenalin på kroppen?

8. Når settes produksjon av hormonet adrenalin i gang? 


\section{Vedlegg 6}

\section{Beskrivende statistikk for pretest, posttest og læringsutbytte for alle elevene samlet}

Tabell A. Beskrivende statistikk og normalitetstest (Shapiro-Wilk) for pretest og posttest med omvendt undervisning i begge klassene samlet

\begin{tabular}{|l|l|l|l|l|}
\hline & N & Gjennomsnitt & Standardavvik & Shapiro-Wilk (sig) \\
\hline Pretest & 46 & 4,52 & 2,137 & 0,172 \\
\hline Posttest & 44 & 5,36 & 2,553 & 0,043 \\
\hline & & & & \\
\hline
\end{tabular}

Tabell B. Beskrivende statistikk og normalitetstest (Shapiro-Wilk) for pretest og posttest med tradisjonell undervisning i begge klassene samlet

\begin{tabular}{|l|l|l|l|l|}
\hline & $\mathbf{N}$ & Gjennomsnitt & Standardavvik & Shapiro-Wilk (sig) \\
\hline Pretest & 46 & 4,17 & 2,153 & 0,039 \\
\hline Posttest & 45 & 4,93 & 2,767 & 0,018 \\
\hline
\end{tabular}

Tabell C. Beskrivende statistikk og normalitetstest (Shapiro-Wilk) for læringsutbytte (differansen mellom pretest og posttest) med tradisjonell undervisning og omvendt undervisning i begge klassene samlet

\begin{tabular}{|l|l|l|l|l|}
\hline & $\mathbf{N}$ & Gjennomsnitt & Standardavvik & Shapiro-Wilk (sig) \\
\hline Differanse tradisjonell & 45 & 0,80 & 2,483 & 0,459 \\
\hline Differanse omvendt & 44 & 0,86 & 2,575 & 0,469 \\
\hline
\end{tabular}




\section{Vedlegg 7}

\section{Beskrivende statistikk for pretest, posttest og læringsutbytte hos klasse A og B separat}

Tabell A. Beskrivende statistikk og normalitetstest (Shapiro-Wilk) for pretest og posttest i klasse A med omvendt undervisning

\begin{tabular}{|l|l|l|l|l|}
\hline & N & Gjennomsnitt & Standardavvik & Shapiro-Wilk (sig) \\
\hline Pretest & 24 & 3,29 & 1,829 & 0,107 \\
\hline Posttest & 22 & 4,91 & 2,893 & 0,594 \\
\hline
\end{tabular}

Tabell B. Beskrivende statistikk og normalitetstest (Shapiro-Wilk) for pretest og posttest i klasse A med tradisjonell undervisning

\begin{tabular}{|l|l|l|l|l|}
\hline & $\mathbf{N}$ & Gjennomsnitt & Standardavvik & Shapiro-Wilk (sig) \\
\hline Pretest & 24 & 5,08 & 2,358 & 0,519 \\
\hline Posttest & 23 & 6,30 & 2,183 & 0,040 \\
\hline
\end{tabular}

Tabell C. Beskrivende statistikk og normalitetstest (Shapiro-Wilk) for læringsutbytte av omvendt og tradisjonell undervisning i klasse A

\begin{tabular}{|l|l|l|l|l|}
\hline & N & Gjennomsnitt & Standardavvik & Shapiro-Wilk (sig) \\
\hline $\begin{array}{l}\text { Omvendt undervisning } \\
\text { (diff. posttest og pretest) }\end{array}$ & 22 & 1,7727 & 2,40895 & 0,49 \\
\hline $\begin{array}{l}\text { Tradisjonell undervisning } \\
\text { (diff. posttest og pretest) }\end{array}$ & 22 & 1,2727 & 2,22928 & 0,15 \\
\hline
\end{tabular}

Tabell D. Beskrivende statistikk og normalitetstest (Shapiro-Wilk) for pretest og posttest i klasse B med omvendt undervisning

\begin{tabular}{|l|l|l|l|l|}
\hline & $\mathbf{N}$ & Gjennomsnitt & Standardavvik & Shapiro-Wilk (sig) \\
\hline Pretest & 22 & 5,86 & 1,583 & 0,275 \\
\hline Posttest & 22 & 5,82 & 2,130 & 0,004 \\
\hline
\end{tabular}

Tabell E. Beskrivende statistikk og normalitetstest (Shapiro-Wilk) for pretest og posttest i klasse B med tradisjonell undervisning

\begin{tabular}{|l|l|l|l|l|}
\hline & N & Gjennomsnitt & Standardavvik & Shapiro-Wilk (sig) \\
\hline Pretest & 22 & 3,18 & 1,368 & 0,029 \\
\hline Posttest & 22 & 3,50 & 2,614 & 0,175 \\
\hline
\end{tabular}

Tabell F. Beskrivende statistikk og normalitetstest (Shapiro-Wilk) for læringsutbytte av omvendt og tradisjonell undervisning i klasse B

\begin{tabular}{|l|l|l|l|l|}
\hline & N & Gjennomsnitt & Standardavvik & Shapiro-Wilk (sig) \\
\hline $\begin{array}{l}\text { Omvendt undervisning } \\
\text { (diff. posttest og pretest) }\end{array}$ & 22 & $-0,0455$ & 2,45875 & 0,369 \\
\hline $\begin{array}{l}\text { Tradisjonell undervisning } \\
\text { (diff. posttest og pretest) }\end{array}$ & 22 & 0,3182 & 2,73228 & 0,413 \\
\hline
\end{tabular}




\section{Vedlegg 8}

\section{Beskrivende statistikk for sammenligning av klassenes utgangspunkt}

Tabell A. Beskrivende statistikk og normalitetstest (Shapiro-Wilk) for resultatet på pretest om begge temaene samlet (syn og hormoner) hos klasse A og B

\begin{tabular}{|l|l|l|l|l|}
\hline & N & Gjennomsnitt & Standardavvik & Shapiro-Wilk (sig) \\
\hline Klasse A (poengsum pretest) & 48 & 4,19 & 2,275 & 0,208 \\
\hline Klasse B (poengsum pretest) & 44 & 4,52 & 1,994 & 0,061 \\
\hline
\end{tabular}

Tabell B. Beskrivende statistikk og normalitetstest (Shapiro-Wilk) for resultatet på pretest om temaet syn hos klasse A og B

\begin{tabular}{|l|l|l|l|l|}
\hline & N & Gjennomsnitt & Standardavvik & Shapiro-Wilk (sig) \\
\hline Klasse A (poengsum pretest) & 24 & 3,29 & 1,829 & 0,107 \\
\hline Klasse B (poengsum pretest) & 22 & 3,18 & 1,368 & 0,029 \\
\hline
\end{tabular}

Tabell C. Beskrivende statistikk og normalitetstest (Shapiro-Wilk) for resultatet på pretest om temaet hormoner hos klasse A og B

\begin{tabular}{|l|l|l|l|l|}
\hline & N & Gjennomsnitt & Standardavvik & Shapiro-Wilk (sig) \\
\hline Klasse A (poengsum pretest) & 24 & 5,08 & 2,358 & 0,519 \\
\hline Klasse B (poengsum pretest) & 22 & 5,86 & 1,583 & 0,275 \\
\hline
\end{tabular}




\section{Vedlegg 9}

\section{Beskrivende statistikk for figur 3}

Tabell A. Beskrivende statistikk og normalitetstest (Shapiro-Wilk) for andelen elever som sa de gjorde hjemmearbeid i forbindelse med omvendt og tradisjonell undervisning. Alle elevene samlet

\begin{tabular}{|l|l|l|l|l|}
\hline & N & Gjennomsnitt & Standardavvik & Shapiro-Wilk (sig) \\
\hline Omvendt undervisning & 41 & 0,66 & 0,48 & 0,000 \\
\hline Tradisjonell undervisning & 44 & 0,64 & 0,49 & 0,000 \\
\hline
\end{tabular}

Tabell B. Beskrivende statistikk og normalitetstest (Shapiro-Wilk) for andelen elever i klasse A som sa de gjorde hjemmearbeid med omvendt og tradisjonell undervisning

\begin{tabular}{|l|l|l|l|l|}
\hline & N & Gjennomsnitt & Standardavvik & Shapiro-Wilk (sig) \\
\hline Omvendt undervisning & 20 & 1,00 & 0,00 & 0,000 \\
\hline Tradisjonell undervisning & 22 & 0,77 & 0,43 & 0,000 \\
\hline
\end{tabular}

Tabell C. Beskrivende statistikk og normalitetstest (Shapiro-Wilk) for andelen elever i klasse B som sa de gjorde hjemmearbeid med omvendt og tradisjonell undervisning

\begin{tabular}{|l|l|l|l|l|}
\hline & N & Gjennomsnitt & Standardavvik & Shapiro-Wilk (sig) \\
\hline Omvendt undervisning & 21 & 0,33 & 0,48 & 0,000 \\
\hline Tradisjonell undervisning & 22 & 0,50 & 0,51 & 0,000 \\
\hline
\end{tabular}

Tabell D. Beskrivende statistikk og normalitetstest (Shapiro-Wilk) for andelen elever i klasse A og klasse B som sa de gjorde hjemmearbeid

\begin{tabular}{|l|l|l|l|l|}
\hline & N & Gjennomsnitt & Standardavvik & Shapiro-Wilk (sig) \\
\hline Klasse A & 42 & 0,88 & 0,33 & 0,000 \\
\hline Klasse B & 43 & 0,42 & 0,50 & 0,000 \\
\hline
\end{tabular}

Tabell E. Beskrivende statistikk og normalitetstest (Shapiro-Wilk) for andelen elever i klasse A og klasse B som sa de gjorde hjemmearbeid i forbindelse med tradisjonell undervisning

\begin{tabular}{|l|l|l|l|l|}
\hline & $\mathbf{N}$ & Gjennomsnitt & Standardavvik & Shapiro-Wilk (sig) \\
\hline Klasse A & 22 & 0,77 & 0,43 & 0,000 \\
\hline Klasse B & 22 & 0,50 & 0,51 & 0,000 \\
\hline
\end{tabular}

Tabell F. Beskrivende statistikk og normalitetstest (Shapiro-Wilk) for andelen elever i klasse A og klasse B som sa de gjorde hjemmearbeid i forbindelse med omvendt undervisning

\begin{tabular}{|l|l|l|l|l|}
\hline & $\mathbf{N}$ & Gjennomsnitt & Standardavvik & Shapiro-Wilk (sig) \\
\hline Klasse A & 20 & 1,00 & 0,00 & 0,000 \\
\hline Klasse B & 21 & 0,33 & 0,48 & 0,000 \\
\hline
\end{tabular}




\section{Vedlegg 10}

\section{Elevenes utsagn organisert i kategoriene kompetanse, tilhørighet, autonomi og direkte utrykk for autonom motivasjon}

Tabell 1. Kompetanse

\begin{tabular}{|l|l|l|l|l|}
\hline $\begin{array}{l}\text { Spørsmål } \\
\text { (intervju) }\end{array}$ & gA & jA & gB & jB \\
\hline 1 & $\begin{array}{l}\text { Likte videoen fordi } \\
\text { det er bedre å få } \\
\text { ting forklart enn å } \\
\text { lese det selv }\end{array}$ & $\begin{array}{l}\text { Bedre med tavle, } \\
\text { fordi man kanskje } \\
\text { ikke husket filmen }\end{array}$ & $\begin{array}{l}\text { Lærte mye av } \\
\text { filmen, og kunne jo } \\
\text { bare sjekke boka } \\
\text { hvis det var noe jeg } \\
\text { glemte }\end{array}$ \\
\hline 3 & $\begin{array}{l}\text { Enig } \\
\text { (tror jeg lærte ca } \\
\text { like mye) }\end{array}$ & $\begin{array}{l}\text { Tror jeg lærte ca } \\
\text { like mye }\end{array}$ & $\begin{array}{l}\text { Ganske likt hvor } \\
\text { mye vi lærte }\end{array}$ & $\begin{array}{l}\text { Enig } \\
\text { (ganske likt hvor } \\
\text { mye vi lærte) }\end{array}$ \\
\hline 3 & $\begin{array}{l}\text { Enig } \\
\text { (kanskje bedre for } \\
\text { dem som ikke er så } \\
\text { glad i å lese) }\end{array}$ & $\begin{array}{l}\text { Enig } \\
\text { (kanskje bedre for } \\
\text { dem som ikke er så } \\
\text { glad i å lese) }\end{array}$ & $\begin{array}{l}\text { Enig } \\
\text { (kanskje bedre for } \\
\text { dem som ikke er så } \\
\text { glad i å lese) }\end{array}$ & $\begin{array}{l}\text { Kanskje bedre for } \\
\text { dem som ikke er så } \\
\text { glad i å lese }\end{array}$ \\
\hline 5 & $\begin{array}{l}\text { Jeg klarte å bruke } \\
\text { det jeg hadde lært i } \\
\text { videoen i } \\
\text { aktivitetene }\end{array}$ & $\begin{array}{l}\text { Ja } \\
\text { (jeg klarte å bruke } \\
\text { det jeg hadde lært i } \\
\text { videoen i } \\
\text { aktivitetene) }\end{array}$ & $\begin{array}{l}\text { Ja } \\
\text { (jeg klarte å bruke } \\
\text { det jeg hadde lært i } \\
\text { videoen i } \\
\text { aktivitetene) }\end{array}$ & $\begin{array}{l}\text { Ja } \\
\text { (jeg klarte å bruke } \\
\text { det jeg hadde lært i } \\
\text { videoen i } \\
\text { aktivitetene) }\end{array}$ \\
\hline
\end{tabular}

Tabell 2. Tilhørighet

\begin{tabular}{|c|c|c|c|c|}
\hline $\begin{array}{l}\text { Spørsmål } \\
\text { (intervju) }\end{array}$ & gA & $\mathrm{jA}$ & gB & $\mathrm{jB}$ \\
\hline 1 & $\begin{array}{l}\text { Blir litt annerledes } \\
\text { og nytt, og da enga- } \\
\text { sjerer vi oss mer }\end{array}$ & & & $\begin{array}{l}\text { Var artig med } \\
\text { oppgaver i gruppe! }\end{array}$ \\
\hline 2 & $\begin{array}{l}\text { Også holdt vi ikke } \\
\text { på så lenge }\end{array}$ & $\begin{array}{l}\text { Enig } \\
\text { (så holdt vi ikke på } \\
\text { så lenge) }\end{array}$ & $\begin{array}{l}\text { Enig } \\
\text { (så holdt vi ikke på } \\
\text { så lenge) }\end{array}$ & $\begin{array}{l}\text { Enig } \\
\text { (så holdt vi ikke på } \\
\text { så lenge) }\end{array}$ \\
\hline 2 & $\underline{\text { Vi rakk ikke bli lei }}$ & $\begin{array}{l}\text { Enig } \\
\text { (vi rakk ikke bli lei) }\end{array}$ & $\begin{array}{l}\text { Enig } \\
\text { (vi rakk ikke bli lei) }\end{array}$ & $\begin{array}{l}\text { Enig } \\
\text { (vi rakk ikke bli lei) }\end{array}$ \\
\hline 3 & & & $\begin{array}{l}\text { Ganske likt hvor mye } \\
\text { vi lærte }\end{array}$ & $\begin{array}{l}\text { Ja } \\
\text { (ganske likt hvor } \\
\text { mye vi lærte) }\end{array}$ \\
\hline
\end{tabular}

Tabell 3. Autonomi

\begin{tabular}{|l|l|l|l|l|}
\hline $\begin{array}{l}\text { Spørsmål } \\
\text { (intervju) }\end{array}$ & gA & jA & gB & jB \\
\hline 1 & & & $\begin{array}{l}\text { Lærte mye av filmen, og kunne jo } \\
\text { bare sjekke boka hvis det var noe } \\
\text { jeg glemte }\end{array}$ \\
\hline 4 & $\begin{array}{l}\text { Mer rom for å } \\
\text { prøve ut ting }\end{array}$ & $\begin{array}{l}\text { Enig } \\
\text { (mer rom for å } \\
\text { prøve ut ting) }\end{array}$ & & \\
\hline
\end{tabular}


Tabell 4. Direkte uttrykk for autonom motivasjon

\begin{tabular}{|c|c|c|c|c|}
\hline $\begin{array}{l}\text { Spørsmål } \\
\text { (intervju) }\end{array}$ & gA & jA & gB & jB \\
\hline 1 & Jeg likte postene & & & $\begin{array}{l}\text { Artig med opp- } \\
\text { gaver i gruppe! }\end{array}$ \\
\hline 1 & $\begin{array}{l}\text { Annerledes og nytt } \\
\text { og da engasjerer vi } \\
\text { oss mer }\end{array}$ & Likte videoen & & \\
\hline 1 & $\begin{array}{l}\text { Jeg ville hatt om- } \\
\text { vendt undervisning } \\
\text { igjen }\end{array}$ & $\begin{array}{l}\text { Ja } \\
\text { (jeg ville hatt } \\
\text { omvendt } \\
\text { undervisning igjen) }\end{array}$ & $\begin{array}{l}\text { Ja } \\
\text { (jeg ville hatt } \\
\text { omvendt } \\
\text { undervisning } \\
\text { igjen) }\end{array}$ & $\begin{array}{l}\text { Ja } \\
\text { (jeg ville hatt } \\
\text { omvendt under- } \\
\text { visning igjen) }\end{array}$ \\
\hline 2 & $\begin{array}{l}\text { Ble noe nytt hele } \\
\text { tiden føltes det som, } \\
\text { så vi rakk ikke bli lei }\end{array}$ & $\begin{array}{l}\text { Mer lei av å bare } \\
\text { skrive oppgaver enn } \\
\text { å gjøre aktiviteter }\end{array}$ & & \\
\hline 2 & & $\begin{array}{l}\text { Blir liksom mer } \\
\text { spennende da }\end{array}$ & & \\
\hline 3 & $\begin{array}{l}\text { Enig } \\
\text { (fikk mer lyst til å } \\
\text { lære av aktivitetene) }\end{array}$ & $\begin{array}{l}\text { Fikk mer lyst til å } \\
\text { lære av aktivitetene }\end{array}$ & $\begin{array}{l}\text { Mer morsomt } \\
\text { med omvendt } \\
\text { hjemme }\end{array}$ & $\begin{array}{l}\text { Ja } \\
\text { (mer morsomt med } \\
\text { omvendt hjemme) }\end{array}$ \\
\hline 3 & $\begin{array}{l}\text { Enig } \\
\text { (fikk mer lyst til å } \\
\text { lære av videoen) }\end{array}$ & $\begin{array}{l}\text { Fikk mer lyst til å } \\
\text { lære av videoen }\end{array}$ & $\begin{array}{l}\text { Mer morsomt } \\
\text { med omvendt } \\
\text { på skolen }\end{array}$ & $\begin{array}{l}\text { Ja } \\
\text { (mer morsomt med } \\
\text { omvendt på skolen) }\end{array}$ \\
\hline
\end{tabular}

